Historic, Archive Document

Do not assume content reflects current scientific knowledge, policies, or practices. 


\section{A Message From The President}

To our myriads of valued customers and to our faithful representatives who have been the medium through which we have distributed our general line of high grade nursery stock for the past several years and who have so ably assisted our customers with their planting and orchard problems, we dedicate this NEW PRICE LIST on and the accurate nomenclature and descriptions of the many items we are producing and selling.

We have a favorable soil and climate for the producing of a high grade of stock, besides we employ none except experienced and capable employees, which insures nothing but the very best. We guarantee every item we ship to be strictly first-class and to satisfy. Because of our increased volume of business, we have very noticeably lowered our prices on everything. Other firms may undersell us, but be assured they do not do so and at the same time furnish the same high grade stock and service that we do.

Altho we are listing a general line of nursery stock, there are many items that for lack of space, we left out. Please write for prices on any item which you do not find listed and they will be immediately quoted and correct descriptions given. Our representatives are courteous, well informed and besides their ability to help you in the development of orchards, they are capable of rendering expert service in the scientific arrangement of ornamentals and the development of your landscape in the latest vogue or fashion.

With grateful appreciation of your past valued patronage and kindly soliciting a continuance of same, assuring you in return the best stock, the lowest prices, personal and prompt attention to all inquiries and orders, we beg to remain

Very truly yours,

J. R. BRAGG, President 


\section{Terms and Conditions of Sale}

Prices quoted in this catalog cancel all previous lists and are subject to change without notice. Prices include delivery to your premises, packing, boxing or baling free.

All plants are packed carefully to prevent drying or freezing while in transit.

All plants are guaranteed true to name, full count, up to grade and in good condition when shipped. We will replace any plant or tree proving untrue to name. Our nursery stock is of the highest quality, thrifty, well grown, insuring its success if properly cared for after transplanted in your soil. As we have no control over its care and treatment after it is carefully packed and shipped, we can give no warranty on the life of the stock; however, any just complaint will receive our careful attention and consideration. Claims must be made prcmptly on receipt of stock. Plants delivered as per order and in good condition are not returnable.

\section{TERMS: CASH ON DELIVERY.}

Guarantee: We are very careful to keep each variety true to name, as labeled and are ready at any time to replace, on proper proof, any that may prove otherwise, free of charge, or refund the amount paid, but it is mutually agreed between the purchaser and ourselves that we shall at no time be liable for an amount greater than the original purchase price.

LOCATION-McMinnville is located in Middle Tennessee, on N. C. \& St. L. Railway. It is also located on State Highway No. 1, a hard surface highway through the state. It is also located on the Broadway of America.

Our shipping season begins usually early in October and lasts through the winter until about May 1st. Stock dug with balls of earth may be successfully transplanted at even earlier or later dates. We shall be glad to advise best time for planting any item of nursery stock in our catalog. In the absence of one of our well informed representatives, address your correspondence to Cumberland Valley Nursery Co., Inc., McMinnville, Tennessee and your inquiries or orders will be given our personal attention. 
INIEX

Apples Pages $5-6$

Pears $6-7$

Plums

Apricots 7-8

Quince

Cherries

Peaches

$9-10$

Grapes

$10-11$

Raspberries

Blackberries

$11 \quad 12$

Currants

Gooseberries

Dewberries

Pecans

$13-14$

Rhubarb

Asparagus

Mulberry

Deciduous Shrubs

$14,15,16,17,18,19,20$

Broadleaf Evergreens

$20-21$

Conifers

$23,24,25,26,27,28$

Vines and Creepers $29-30$

Shades $30-31$

Roses $31-32-33$

Perennials $33-34-35$ 


\section{FRUIT TREES}

\section{APPLES}

Sizes
3 to
4 teet

\section{EARLY APPLES}

Varieties :

\section{YELLOW TRANSPARENT}

A Russian apple of splendid quality. The hardiest and most extensively carly apple in this section. Ripens ten days earlier than Early Harvest. Fruit large, pale yellow, sub-acid. A very young bearer and one of the best market sorts.

\section{EARLY HARVEST}

Medium size; roundish, smooth, bright straw color when ripe; flesh nearly white, rather acid, fine. Ripens a week later than Yellow Transparent and for three weeks afterward. Productive. An old-tine favorite cooking apple.

\section{RED JUNE}

Conical shaped, medium size; deep red skin; white, juicy flesh. Ripens in Junc and July.

\section{YELLOW HORSE}

A well known variety of large size; greenish yellow skin, acid. Excellent for canning and drying and is a heavy bearer. July and August.

\section{FALL APPLES}

\section{GRIMES GOLDEN}

This gelden apple has excellent quality and no doubt one of the most popular varieties. It is recognized as the best pollinizer and is being planted in orchards with other varieties as a polliniz'r.

\section{WEALTHY}

Large, shaded to dark red, quality good, tender and productive. Early to bear and exceedingly satisfactory.

\section{NORTHERN SPY}

Large, striped crimson in the sun, juicy, rich and aromatic, retaining these qualities until late spring or summer. The tree grows rapidly, bears well as it blooms later than most varieties. Valuable as an aphis resisting sort.

\section{WINTER APPLES}

\section{DELICIOUS}

Flourishes well here as in every state of the Union. Bears annually; great yielder; fruit hangs well on trees. Trees very thrifty, long lived and extremely hardy. Fruit very large, nearly coverid with brilliant, dark red; flesh fine grained, crisp juicy, melting and delicious; splendid keeper and shipper; should be in every orchard.

\section{ROME BEAUTY}

Large; yellow and bright red; flesh yellowish, tender, juicy, sub-acid; tree moderate grower, good bearer.

\section{WINESAP}

It is one of the viry best keepers. Medium size, smooth and a fine dark red; flesh yellow, crisp, tender, very juicy, aromatic, firm and very good. Popular with fruit stores because it always holds up and is one of the leading cxport apples. The tree is a strong grower, the root growth being exceptibnally strong. It comes into Learing early and is remarkable for its regular and abundant crops.

\section{STAYMAN WINESAP}

Dark, rich red, indistinctly striped; larger than old Winesap. Tree producrive and a drought resister. 


\section{BALDWIN}

S ason. December to March. The great commercial late winter keeper of the East,rn States. Tree a vigorous open grower, upright in tendency aud very productive where hardy. Comes slow into bearing, but producis abun dantly when mature. Fruit large, rounded. deep red; flesh rich, crisp and juicy.

\section{JONATTHAN}

One of th. best commercial varieties. Medium sized, oblate, striped skin of yellow and red, white stained flesin, juicy, tender, deliciously sub-acid, if fine quality. A popular export variety. Late fall and early winter.

\section{YORK IMPERIAL}

A late kicping commercial variety, shaded red on yellowish skin, flesh firm and tree healthy. Regular and heavy bearer. Plant for profit or for home.

\section{MAMMOTH BLACK TWIG}

A seedling of Winesap, greatly resembling the mothir tree, but growing more vigorously and bearing larger fruit. A large red apple of good appearing. eating and keeping qualities.

\section{WINTER BANANA}

One of the most dep. ndable apples for all districts. Large, handsome fruits, clear waxen yellow with a delicate blush. A delightful flavor and aroma. Ripens fairly early and does better than most apples in the lower altitudes. September.

\section{MCINTOSH}

Bright, deep red; fine quality. Ripens in Septimber; can be in common storage late in winter.

\section{CRAB APPLES}

\begin{tabular}{|c|c|}
\hline Sizes & \\
\hline 310 & + feet \\
\hline to & 5 fcet \\
\hline
\end{tabular}

to 5 ret

\section{HYSLOP}

Season. September to October. Tree vigorous where hardy; blights in some localities. Fruit medium; yellow grounded with heavy shadings of deep crimson and splashes of maroon with heavy blue bloom; flesh fine, firm, yel low. astringent: bears abundantly in clusters, which make tree exceedingly ornamental. Its high color always commands a fancy market price for it. One of the most desirable sorts for culinary purposes.

\section{TRANSCENDENT}

Season. Scptember. Fruit midium to large; color brownish-yellow with blush of carmine: flesh firm and crisp, yellowish, fine grained, very juicy, acid. Tree is a vigorous grower. Hardy. Subject to blight and sbould not be plantid near other orchard treees.

\section{WHITNEY}

Season, August. Fruit large to very large for a bybrid; yellow, striped with red and mostly covers with red on sunny side; flesh yellow, very juicy and fine grained; flavor rich and almost swect.

\section{PEARS}

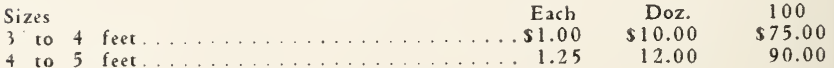

to 5

Varieties:

\section{BARTLETT}

Large size. Golden yellow wh n ripe. with a beautiful blush next the sun. Buttery, very juicy, and highly flavored; tree a strong grower, bears early and abundantly: very popular. August, Septembar.

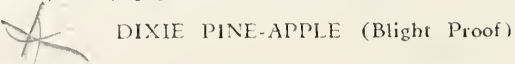

A large size pear and the trce is a very prolific bearer. The fruit is very delicious and always commands a high market price. It is canned extensively and considered absolutely blight proof. It is being planted commercially to a great extent, and is a good keeper and shipper. 


\section{EARLY HARVEST}

Large, buttery yellow skin; very juicy and highly flavored, early and a great bearer.

\section{GARBER}

Large, bright yellow with red. juicy and good; a splendid canning pear, tree vigorous and hardy, not subject to blight; ripens just after Bartlett.

\section{KEIFFER}

Large, golden yellow, often blushes in the sun; juicy and melting. One of the best for canning and preserving; the most profitable to grow. Tree hoalthy, hardy and vigorous. Does not succeed on quince, therefore no dwarfs should be planted. Keiffer receives more praise and commendation than any other. It is liable to overbear, therefore special pains should be taken to thin the fruit.

\section{SUGAR (Seckel)}

Small, rich golden brown: flesh very fine grained, sweet, juicy, melting. buttery. Regarded as the standard of excellence among pears. Tree stout, slow grower, hardy and blight resistant. Sells because of superior qaailty; in demand for canning and pickling.

\section{PLUMS}

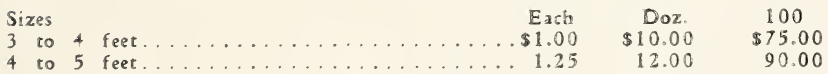

4 to 5 feet. . . .

Varieties:

\section{ABUNDANCE}

One of the best Japan plums. Tree is very rapid grower, healthy and comes into bearing quite young and yields abundantly; medium size, rich, bright cherry red with distinct bloom and highly perfumed; flesh light yellov, juicy and tender, and excellent quality. Tree vigorous and hardy.

\section{RED JUNE}

A very handsome plum, about a week earlier than Abundance. By all odds the best Japanese plum ripening before Abundance. Medium to nearly large size, deep vermilion red, with handsome bloom and very showy; flesh light lemon-yellow or whitish, firm and moderately juicy; very slightly subvigorous and succeeds in all sections of the country.

acid to sweetish, of good pleasant quality; pit small; tree upright, spreading,

\section{WICKSON}

Large, heart shaped, deep maroon red; flesh very firm, yellow, sub-acid, rich and good; a good shipping plum; tree uqright; shy bearer in some localicies.

\section{KELSY JAPAN}

One of the fincst shipping plums. Very large, heart-shaped; greenish-yellow, blushed with red; flesh yellow, firm and of fine quality, Because of its lateness and shipping qualities it has been very profitable commercially. September.

\section{SHROPSHIRE DAMSON}

This variety has been a standard for years and is the most extensively planced plum in this section. Trees are upright in character of growth and usually bear great crops when given congenial soil. Succeeds everywbere plums will grow. Sure demand at local markets.

\section{GERMAN PRUNE}

A valuabls plum of fair quality for dessert, but most esteemed for drying and preserving. Large, long-oval, purole, with a thick blae bloom: flesh firm, sweet and pleasant, separating from the stone. Moderate to vigorous in growtb. September.

\section{APRICOTS}


Varietics:

\section{MOORPARK}

One of the largest, most popular and widely disseminated apricot; deep orange or brownish red; flesh quite firm, bright orange, parting freely from the stone; quite juicy with a rich and luscious flavor; a favorite canning variety. In some sections a shy and irregular bearer. August.

\section{EARLY GOLDEN}

Small, pale orange in color. Flesh yellow, sweit and juicy. Tree hardy and well adapted for Southern planting.

\section{ROYAL}

Large, roundish-oval; pale orange with faintly tinged red cheek: flesh ycllow, frm, sweet, high flavored, slightly sub-acid and good quality, ripens 2 week earlier than Moorpark; a good mark't variety.

\section{QUINCE}

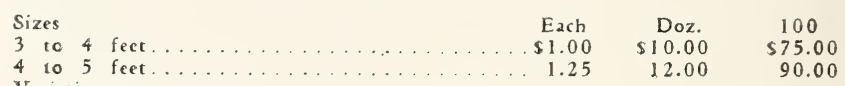

4105
Varietics:

ORANGE

Fruit large, bright yellow, of excellent quality,

\section{CHAMPION}

A prolific and constant $b$ arer of oval fruit, averaging larger than Orange and ripening later. $\AA$ longer keeper.

\section{CHERRIES}

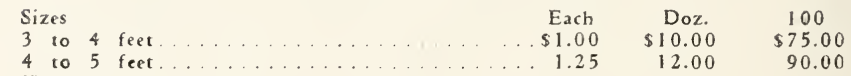

Varieties:

\section{BLACK TARTARIAN (Sweet)}

One of the best swcet cherries. Purplish red cherries of medium size and cxcellent quality. Trees are fruitful, healthy and regular bearers.

\section{GOVERNOR WOOD (Sweet)}

The early wax cherry. Light yellow; extremely sweet, juicy, rich flavor. Good size, finest quality. Tree vigorous and productive. A variety no home orchard should be without.

\section{EARLY RICHMIOND (Sour)}

This old standard cherry has been the favorite for a number of years. In quality it is tart and very valuable for canning purposes. It yiclds nearly every year and reddens the tree with its wonderful crop. It scceeds everywhere chrries will grow and as it is the earliest in season of bearing it is very popular.

\section{LARGE MONTMORENCY (Sour)}

The largest and best of the sour varieties, and the most extensivcly planted commercial variety. A cherry of the Richmond class, but larger and more solid. An upright grower, hardy, heavy cropper. Ripens from seven to ten days later than the Richmond, entirely escaping danger from spring frost. A valuable addition to your orchard fruit.

\section{MAY DUKE (Sour)}

This ripens a little earlier than the preceding varicty and, while not quite so vigorous in tree, the fruit is slightly superior. It is an old variety and has been tested and found worthy of a place in all catalogs.

\section{DYEHOUSE (Sous)}

Bright red, prolific bearer. The fruit is mildly sub-acid, excellent variety for canning, good shipper. Frec and vigorous. Last of May. 


\section{PEACHES}

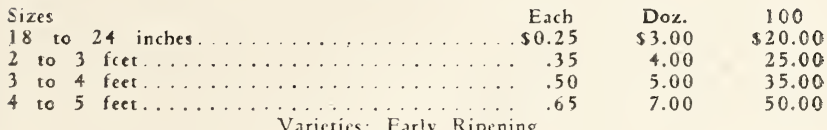

MAYFLOWER (Free)

The earliest of all peaches, and because of this, greatly in demand both for home orchards and commercial plantings. Medium sized fruit, creamy white, heavily blushed and mottled with dark red. Firm and of good quality for an early each. May.

\section{EARLY ROSE (Free)}

This is one of the earliest peaches, ripening shortly aftce Mayflower. White, semi-freestone.

\section{RED BIRD CLING (Cling)}

A strikingly handsome very early shipping peach. Very large, creamy white, flushed with deep red. June.

Varieties: Second Ripening

\section{BELL OF GEORGIA (Free)}

Largi size; white skin with deep red cheek; white flesh. firm and fine flavor; heavy bearer. Best canninng qualities of any peach on the market, but too soft to have shipping qualities of Elberta and Hale. Tree vigoroes and rapid grower. Fruit ripens early part of August.

\section{HILEY (Free)}

Seedling of, and ripens a week before the Belle of Georgia. Superior cuality, one of the bist shipping or canning varieties. Large, white with red cheek, white fiesh, heavy bearer, ripens last of July.

\section{CARMAN (Seni-cling)}

One of the heaviest bearers, large size, creamy white, reddish check on sunny side, very tender flesh, semi-cling. Profitable variety for commercial orchards. Rip ns about the middle of July.

\section{EARLY ALBERTA (Free)}

A clear yellow with blush, fine grained and sweet. Trec a stromg grower, with a tendency to thin itself, carrying moderatc loads of fruit.

\section{CHAMPION (Free)}

Often looked upon as the standard by which to gauge all white-fleshed freestoncs. This variety has everything a peach should bave-size, tender fiesh, juicyness, a honeyed flayor, atractive appearance and a productive tree. Early August.

\section{CRAWFORD EARLY (Free)}

Large, roundish, bright, yellow with red che k; flesh yellow, juicy and sweet; quality good. August and September.

\section{ELBERTA (Frec)}

Beautiful yellow, large and shaded with diep red. Elberta bas been tbe peach for years and is just as good today. The fact that more than eighty per cent of commercial plantings are of this varicty speaks will enough for it. August 15.

\section{J. H. HALE (Free)}

A large, smooth peach having no fuzz. Deep red; flesh yellow. Fine quality. Middle to last of July.

\section{ROCHESTER (Free)}

Large, yellow and red peach. Flesh ycllow, of fine quality and exquisite flavor. Stone very small and will ship as well as Elberta. The tree comes into bearing when very young, is a strong, upright grower and is as hardy as an oak. Has produced a full crop after undergoing a temperature of 16 degrees below zero, which killed all the buds on Elberta and Crawford in the same orchard. 


\section{Varieties: Late Ripening}

\section{HEATH CLING (Cling)}

Very large, creamy-whit with delicate red blush; flesh white, slightly red at the pit; tender, juicy and sweet; a valuable sort for canning and one that commands fancy prices in all markets. Early September.

\section{KRUMMEL (Fr:e)}

One of the latest freestone peaches and a profitable market variety. Fruit large, lemon yellow, lightly blushed with carmine; flesh yellow, red at pit; melting, vinous and very good. Tree hardy and productive, usually needs thinring to make good size fruit. Late of September.

\section{LATE CRAWFORD (Frec)}

Large, yellow or greenish-yellow, with dull red cheek; flesh yellow, stained red at pit; melting, vinous and very good. Tree hardy and productive, usually needs thinning to make good size fruit. Late of September.

one of the latest.

\section{GRAPES}

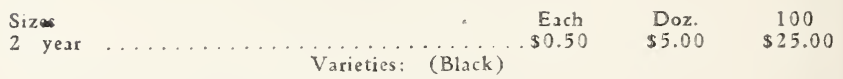

\section{CAMPBELL'S EARLY}

$\AA$ new, very large and fine early grape, black; strong, vigorous, hardy vine with thick, healthy lcaves; clusters very large, usually shouldered, compact and handsome; berries large, nearly roind, black, rich, sweet, verygood; skin thin; seeds round, few and small, parting easily from the pulp; a good shipper. Ripens very early, but remains sound on the vines for many weeks. This makes it one of the most satisfactory and profitable market sorts to grow.

\section{MOORE'S EARLY}

A large grape, ripening a week earlier than Concord; good grower; berries large, good quality. and makes a moderate yield; very valuable as an early grape.

\section{CONCORD}

Decidedly the most popular grape in America, as it adapts itself to vary. ing conditions, and is profitably grown in every grape growing state in the Union. Bunch is large, shoulder:d and compact. Big berries, covered with a rich bloom; purplish black; skin is tender, but amply firm to carry well to distant markets. Flesh juicy, hardy, productive. The most reliable and profitable market variety.

\section{WORDEN}

Seediing of the Concord, which it gratly resembles in appearance and flavor, but the berries are larger. The fruit is said to be better flavored and to ripen several days earlicr. These qualities will give it the foremost rank among native grapes.

\section{Varieties: (White)}

\section{NIAGARA}

Occupies the same position among the white varieties as Concord among the black. Bunch and berrics large, greenish white, changing to pale yellow when fully ripe. Skin thin but tough, quality much like the Concord.

\section{POCKLINGTON}

Seedling from the Concord. The vine is thoroughly hardy both in wood and foliage; it is a strong grower, never mildews in bine or foliage. The fruit is a light golden yellow, meat juicy and sweet to the center, with litrle or no pulp; bunches very large, some time shouldered; berries round, very large and thickly set. Ripens with the Concord.

$$
\text { Varieties: (Red) }
$$

\section{BRIGHTON}

Bunch larg: shouldered; berries medium to large, round, dark, red, tender, very little pulp, sweet, juicy, slightly aromatic and very good. Ripens eariy. 


\section{CATAWBA}

Bunches medium, shouldered; berries large, deep coppery $r$, becoming purple when ripe; flesh somewhar pulpy; juicy, sweet, aromatic and ricla; one of th elatest.

\section{DELAWARE}

The bunches are small, compact, and sometimes shouldered; berries are small with thin but firm skin; flesh juicy, very sweet and refreshing and of the besr quality for both table use and for wine. Ripens with Concord or a little before; vine is hardy, productive and a moderate grower.

\section{LUTIE}

An old standard variety. The Lutie is very vigorous and produces more fruit than any other variety in the trial grounds It is a red grape, earlier than the Concord and probably more hardy. There are but few fraits, if any, that will produce more fruit per square foot than grapz's. Try tea of these.

\section{RASPBERRIES}

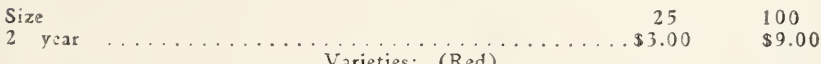

\section{ST. REGIS EVERBEARING}

The new everbearing variety. It gives a crop of fruit all summer and autumn, fruiting oa the old canes in generous quantities until late in August. By this date berries are a bright crimson of large size, and of surprising gual. ity, surgary with fall raspberry flavor. It succeeds upon all soils, whecher light and sandy or cold heavy clay and the canes are absolutely hardy.

\section{CUTHBERT}

Large, bright scarlet-crimson, excellent quality, firm, juicy and refreshing, vigorous grower, hardy and productive; very popular as a home garden and market berry.

\section{KING}

Very early red berry that always commands a good price. The plants are hardy and productive and the King Raspberry is earlier than any otber variety. Varieties: (Black)

\section{CUMBERLAND}

The largest of all black cap; healthy, vigorous grower, throwing up stout, well branched canes thar produce immense crops of magnificent berries. Fruit very large, firm, quality about the samel as Gregg; keeps and shipg well as any of the blacks. The most profitable market variety.

\section{GREGG}

Known for many years by more people than is any other raspbsrry on the market. Large, showy, black, firm and will ship wcll. Hardy and vigozous grower. Ripens about mid-season.

\section{KANSAS}

The great market variety, more generally planted than any other kind: early, large, productive, round, firm, moderately juicy; 2 strong growre:, Handsome appearance; stands shipping well.

\section{BL ACKBERRIES}

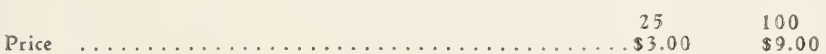

Varieties:

\section{BLOWERS}

Originated in the celebrated small fruit belt of Chautauqua County, New York, where it has been thoroughly tested for several seasons. Claimed to be the hardiest, most productive, the finest quality, and to bring on the market the highest price of all blackberries. Large size, jet back, good shipper, best quality and unexcelled productiveness are the main characteristics of this splea. did new sort. 


\section{EARLY HARVEST}

One of tbe earliest, berry medium sized, good quality and very prolific; firm and attractive in appearance. A good market sort.

\section{ELDORADO}

Vine is vigorous and hardy: herries are very largr, borne in clusters; ripcns well together; sweet, melting and pleasant to the taste.

\section{SNYDER}

Very hardy. great producer, in dium size and one of the best known varieties of blackberries, succeeding wherever planted. Over-production is its greatest fault.

\section{MACDONALD}

New ; very valuable for the "Black Land of Texas." Twenty quarts of fruit bave been gathered from one single plant. Tips like a dewberry.

\section{CURRANTS}

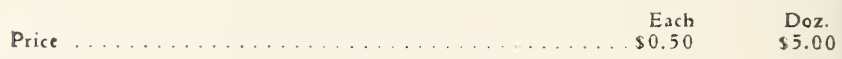

\section{FAY'S IROLIFIC}

For size, beauty and productiven'ss it is a remarkable red currant. The berry is equal to cherry currant, while the flavor is superior. The stem is long, which permits rapid picking, valuable for both market and home. Fruit hangs on well. never dropping as in other currants.

\section{PERFECTION}

Bright red. and of the size larger than the Fay; size of herries is maintained to end of bunch. It is one of the most productive currants. Rich, mild, sub-acid flavor and having plenty of pulp with few sceds. You can pick Perfection fast as cherries.

\section{GOOSEBERRIES}

Price

Each Doz.

Varieties:

$\$ 0.50 \quad \$ 5.00$

\section{HOUGHTON}

Round, dark red when ripe; juicy, swect. Thin, smooth skin. Medium size. The bush is hardy. very productive, free from mildew and the best for general purposes in this section.

\section{DOWNING}

A large, handsome pale green berry of splendid quality for dessert or cooking. Bush upright, robust and sldom mildews. An excellent sort for family or niarket use.

\section{INDUSTRY}

Very large: red: hairy; fine quality; extensively planted for market. Bush upright, strong, and productive. English sort and somewhat liable to mildew. Early.

\section{DEWBERRIES}

\begin{tabular}{|c|c|}
\hline Price & $\begin{array}{c}25 \\
\$ 3.00\end{array}$ \\
\hline
\end{tabular}

\section{LUCRETIA}

A trailing variety of tha blackberry, producing an abundance of large glossy, black. handsome fruit of cxcellent quality; the fruit ripens early and the plant does not sucker.

\section{STRAWBERRIES}


Varieties:

\section{PROGRESSIVE EVERBEARING}

Very large, dark red and glossy: fin: quality. It begins to bear in June with immense crops and continues untal late in fall. It is one of the heaviest bearers of berries in June as well as a markable fall bearer. Will produce a fair crop of fruit the first summer.

\section{AROMA}

This well nkown sort is more largely planted as a commercial berry; the best shipper known. Only modirately prolific, large berry, fine shape, good bright color. carries well. Berry hangs on vine a long time. A variety that holds its own, gaining popularity. Plant healthy, but short rooted. Does not transplant as well as Dunlap. Foiage good and free of disease. S:ll $\mathbf{\$ 1 . 0 0}$ per crate more than ordinary sorts.

\section{KLONDYKE}

Dark red berries, uniform in shape and size, mild and delicious. Plants make a remarkable growth, tall and compact, stalks strong. Leaves light green: abundant runners and an unusual number of crowns. One of the very best paying early varieties. a good shipper. eagerly bought at fancy prices b cause of superior appearance. A good variety for the Southern and Atlantic Coast states.

\section{SENATOR DUNLAP}

This berry is of the Warfield type has a perfect blossoin, is hardy, productive, a splendid keeper and able to hold its own under any "rough and cumble" methods of cultur" to which it is likely to be subjected. It is a very heavy bearer of good size, even fruit. of a very beautifal dark red color. It is a berry to grow for either home use or mark:t.

\section{GANDY}

Introduced over thirty years ago and still grown more commercially than any other sort. Texture is firm, color is bright flame. Althongh the berries are large to very large. flavor is very acid and not of the highest quality. Late to very late in ripening.

\section{ENGLISH WALNUTS}

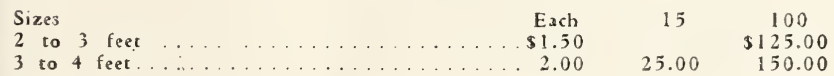

Varieties:

\section{ENGLISH WALNUT}

The planting of English walnuts has been sadly neglected. Thire are a number of trees scattered over this section and in most every instance they have borne abundantly and proven extremely profitable. One tree in this iminediate section has produced as innch as $\$ 80.00$ worth of nuts in one season. The English Walnut will bear as early as an apple and requires very little attention. Order your trees this year.

\section{PECANS}

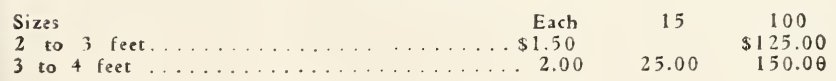

Varieties:

\section{SCHLEY}

Fairly large, rather long. flattened; light brown. shell cracks easily. Of good flavor. The tree is a fre bearer. and the nuts mature early. Considered one of the best.

\section{STUART}

Most extensively planted Pecan because it can be successfuliy grown most anywhere $p$ cans are planted. Bears young. nuts ate large, oblong. thin shell and of the best quality.

\section{SUCCESS}

Of recent introduction. Nut large, cylindrical and tapering at the apex: shell thin, and parting freely from the kernel. which is plump and of good quality. Tres vigorous and a regular cropper. 


\section{MONEYMAKER}

It is an carly bearer, prolific, healthy and remarkably free from not diseases that ruin a great many of our best varieties of pecans. Size medium, toundcd, obling; a bcavy bearer of splendid nuts.

\section{RHUBARB}

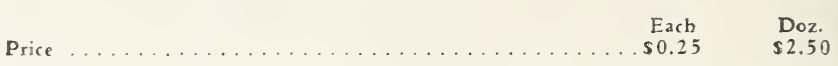

Variety :

\section{LINNAEUS}

Prodices median sized, tender stems in the early spring. This is the old reliable pie kind.

\section{ASPARAGUS}

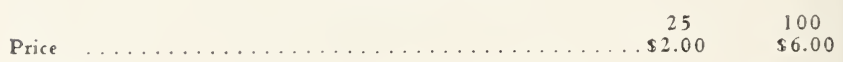

Varieties :

\section{CONOVER'S COLLOSAL}

The standard variety, large and productive; almost universally cultivated in this state.

\section{PALMETTO}

A new variety of Southern origin, and reports indicate that it is equally adapted for all sections. It is earlier, a better yielder, more even and regular in its growth and quality equal to that old favorite, Conover's Colossal.

\section{MULBERRY}

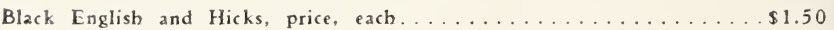

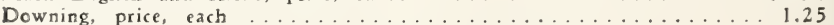
Varieties:

\section{BLACK ENGLISH}

A viry prolific bearer: ripens early. A fine variety to start your rotation with other kinds, providing poultry and hog feed for four or five months.

\section{HICKS}

Wonderfully prolific: fruit sweet; excellent for poultry and hogs. Fruit produced during four months.

\section{DOWNING}

Fruit of rich, sub-acid flavor; last six weeks. Stand winter in Western and Middle stats.

\section{DECIDUOUS SHRUBS}

FLOWERING ALMOND (Pink and White) (Amygdalus nana)

These beautiful shrubs are desirable and scarce. Hardy. Pink and white varieties.

3 to 4 fret.... Each

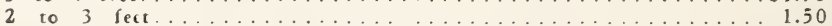

\section{JAPANESE BARBERRY (Berberis Thunbergii)}

A splendid, hardy, dwarf-growing and universally popular shrub. Particularly desirable for massed planting against foundation walls or where a lowgrowing hedge is wanted. Dark green foliage through summer, changing to brilliant orange, scarlet and crimson in fall; practically evergreen in this latitude. Bright red berries appear in summcr and cling ncarly all winter. Thorny branches, a perfect shrub. Grows 2 .0 5 feet.

Size

24 Each

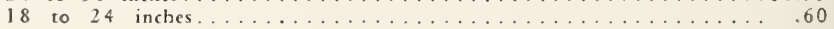

\section{RED LEAF BARBERRY (Berberis Atropurpurea)}

Similar to the Japanse Barberry in habit of growth but foliage is a bronzy red which turns to fiery red in the autumn. Very beautifu! when planted with other shrubs on account of its brilliant color. This shrab is practically new and recuires full sun for best results. 


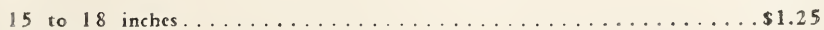

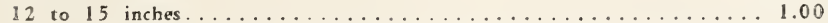

\section{BUTTERFLY BUSH (Buddleia Magnifica) (Summer Lilac)}

Leaves small and narrow, flowers smaller than davidi and color a violet purple. Excellent for massing.

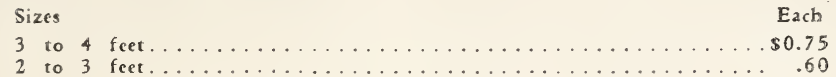

\section{CALYCANTHUS (Floridus--Common Swcetshrub)}

A wcll known native sweet or brown shrub. Quick bush growth, bearing double fragrant chocolate coored fiowers. Booms early in April.

Sizes

Each

2 to 3 feet $\$ 1.25$

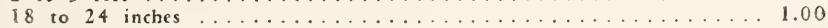

\section{FLOWERING QUINCE (Cydonia Japonica)}

Variously known as Japanese Quince or frebush. Early in the spring the branches arc sprays of coral or bright red blossoms.

Sizes

Each

2 to 3 feet

18 to 24 inches

\section{FLOWERING DOGWOOD (Cornus Florida)}

A sturdy, healthy tree, small, but especially beautiful in early spring when it is covered with large, white, unusual blossoms. A tree that will improve any planting. Use on the lawn or right in with shrubs in the border.

Sizes

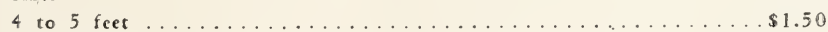

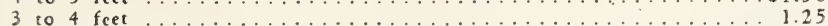

\section{REDFLOWERING DOGWOOD (Cornus Floridus Rubra)}

The popular pink flowering variety so extremcly scarce in the past few years and so much in demand. Our supply of this variety is limited and sold only in connection with other stock. A distinctive shrub for the lawn.

Sizes

Each

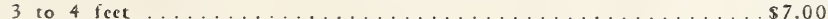

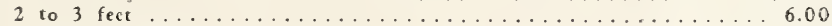

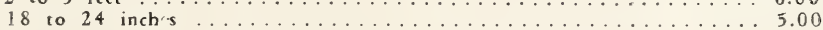

\section{DUETZIA (Gracilis) (Slender Deutzia)}

Flowers pure white, bell-shaped; quite dwarf. This plant blooms early in April and is valuable as a pot plant for winter blooming in conservatory.

Sizes

Each

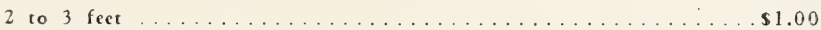

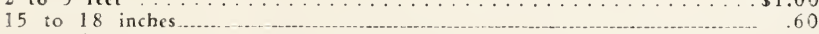

18 to 24 inches.

\section{DEUTZIA (Pride of Rochester)}

Pinkish white. Junc. This variety is very much the same as Deutzia candidissina, but is more popular on account of its color. It is very hardy. adapting itself to any type of soil and if better known would be one of the most popular shrubs planted today.

Sizes

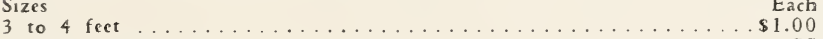

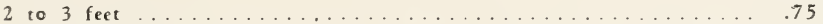

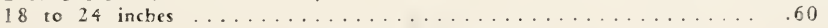

\section{DEUTZIA (Crenata)}

Flowers pure white, single, produced in grat profusion in April. A tall grower. 


\section{PEARL BUSH (Exochorda Grandifiora)}

Large, pure white flowers produced in great profusion arly in March. Whea in full bloom plants bave the appearance of a snowbank. Fine for massing.

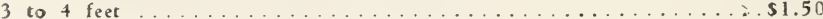

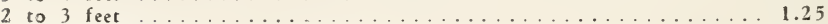

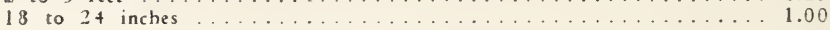

\section{FORSYTHIA (Fortune) (Forsythia Fortunei)}

Vigorous, upright. arched branches with drooping yellow flowirs often with twisted petals appearing in spring b.fore the leaves. Where this shrub has plenty of room to develop it makes a marvelous showing. Grows 8 to 10 feet.

FORSYTHIA (Intermedia) Very fre-blooming

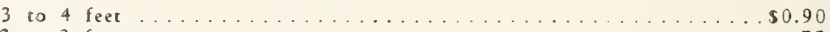

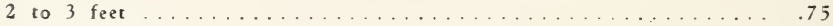

18 to $2+$ inches.........60

FORSYTHIA (Golden Bell) (Viridissiona)

This is often called the Green Stemmed Golden Bell. 6-8 feet. Yellow: Apis. 4.ts is d cided y bie mose porular of all the Golden Bells. The

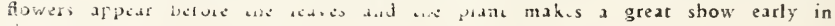
the s, siti...

\section{H1B1SCUS (Shrub Althea) (Bush Form) (Syriacus)}

The flowers are produc d from May until September. When planted in masses of contrasting colors. the effect is most pleasing. The varieties wa offer are narly all of dwarf yrowth and are far superior to th- old sorts. Single. semi-double and double. When ordering state color desired.

Varieties:

Ardens-double violet Doable Precoce-Hesh pink Jean de Arc double flesh pink Lady Stanley-double Hesh pink Sizes

3 to 4 feet

2 to 3 feet

18 to $2+$ inches
Paconitiorus-v ry double, rosy purple Purpurea Semi-pl na-double purple

Snowdrift-single white

Totus Alba single white

\section{PEEGEE HYDRANGEA (Paniculata Grandiflra)}

A beautiful, tall shrub with leaves of bright. shiny green; flowers borne in huge panicles from. 8 to 12 inches long. light pink. changing to brown later in the fall; blooms in August and September; can be grown in tree form successtully and makes a very desirable lawn ornament.

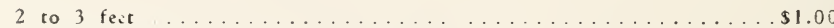

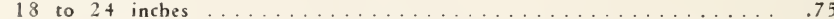

\section{HYDRANGEA HILL OF SNOW (Arboresc ns Grandiflora)}

White. May and June. This magnificent, hardy American shrub is the very finest addition to this class of plants found in many a year. The blooms are of the very largest size, of pure white color and th: foliage is finely finished. One of its most valuable characteristics is its coming into bloom just after the passing of the early spring shrubs: while its long period of bloom from early Jun: through August, makes it doubly valuable, not only to the florist, but to every owner of a garden. Perfectly hardy. Habit of plant exceilent. 


\section{COMMON CRAPEMYRTLE (Lagerstromeia India)}

A vigorous, deciduous shrub of small tree, with beautifully fir:nged fowers in the summer. The crepemyrtle is easy to grow, thriving often when given no care for years. Clumps of thes-1 trees brighten the roadways here and there in the South. When fitted into landscape plantings they are extremely valuable for their color and long sason of bloom. We have red, pink, purple, etc.

Sizes

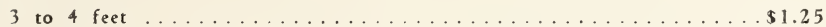

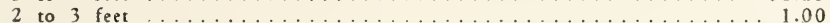

\section{HONEYSUCKLE (Lonicera fragrantissima)}

Highly esteemed for its exce-dingly sweet-scented, pinkish-white flowers which appear in February and continue to bloom for a long time.

Sizes

Each

3 to 4 feet

1.00

2 to 3 feet

18 to 24 inches

\section{MORROW HONEYSUCKLE (Lonicera Morrowi)}

This is one of the best quick growing. compact and "filler" shrubs w" bave. The foliage is bright green. the blossoms cream colored. appearing in April. The red and coral fruits follow from June to Asgust. In dry or moist soil, shade or sun. city or country. this variety will thriv.

Sizes

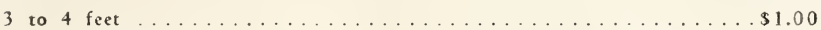

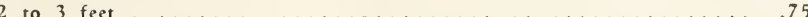

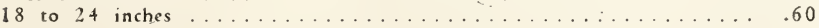

\section{TARTARIAN HONEYSUCKLE (Lonicera Tartarica)}

This is one of the old-time favorite shrubs. It attains about ten feet in beight and is extremely easy to cultivat. The upper lip is deeply divided and spreading.

Sizes

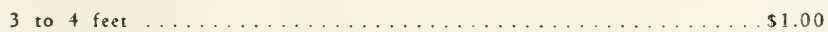

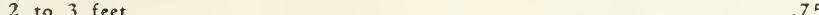

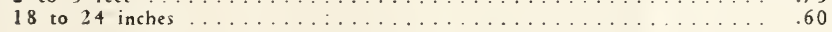

\section{BETCHEL'S CHAB (Malus Ioensis Plena)}

A most inter-sting group of trees, largely natives of the highlands of Western China. They are strong growers. with lovely flowers. followed by ornamental fruits that will attract birds to your garden. Large. double. fragrant, clear pink flowers.

Sizes

Each

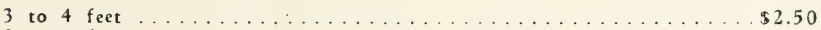

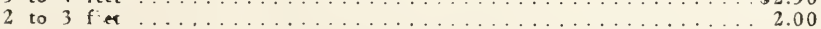

\section{FLOWERING POMEGRANITE (Punica granatum)}

Very valuable. summer-flowering. tall growing shrubs. Perfectly hardy in the South. Flowers are produced in great profusion very early in May, and last almost during the entir- summer. Foliage bright. lustrous green. Very conspicuous and desirable. Blooms are double red. white and variegated.

Sizes

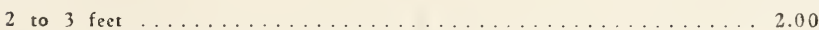

18 to $2+$ inch

\section{MOCK ORANGE (Syringa) (PHILADELPHUS coronarius)}

6 to 8 feet. White. June. The old-fashioned mock orange, well known to everyone because of its waxy white. fragrant flowers. It proves a specially good plant for every use, th: foliage being large. oval in shape and deep green. For cut flowers it is valuable and pruning in this manner often keeps the bush confined where it is not d-sirable to have it grow too tall. Very valuable for background, scieen or grouping. 


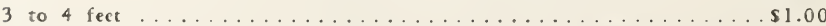

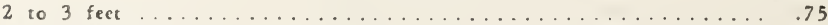

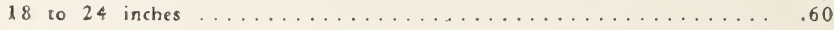

\section{PUSSY WILLOW'S (Salis Caprea)}

$R$ small, shrub-like trce which is quick-growing and has furry carkins in opring which makes it very attractive and desirable.

Sizes

5 to 6 feet

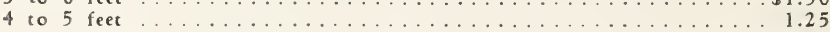

3 to 4 feet $\ldots \ldots \ldots \ldots \ldots$

\section{SPIREA ANTHONY WATERER (Crimson Spirea)}

A dwarf upright variety that seldom cxceeds two feet in height and produces bright crimson blossoms the entire summer and fall. Foliage attractive, being variegated with creamy white or yellow. Us d extensively for border and foundation planting with increasing popularity.

Sizes

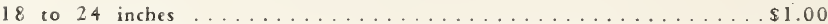

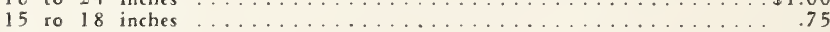

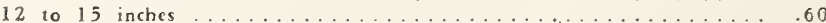

\section{SPIREA COLOSA ALBA (White Japanese Spirea)}

An upright shrub, becoming 18 inches to 2 fcet high. Very profuse bloomer, and continuing in flowers throughout the summer. Flowers pure white, in flat topped clusters.

Sizes

Each

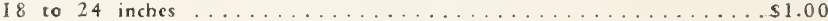

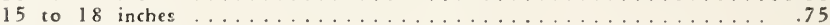

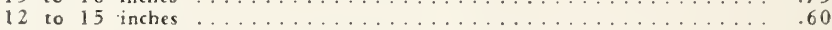

\section{SPIREA PRUNIFOLIA (Bridalwreath Spirea)}

This is an old-fashioned variety, flowcrs borne close to the slender, erect branches in the spring before foliage appears. Th individual flowers resemble miniature roses and are usually borne in great profusion. The foliage is shiny dark green and in the fall turns bright red.

Sizes

Each

2 to 3 feet

18 to 24 inches

\section{SPIREA THUNBERGIl (Thunberg Spirea) (Snow Garland)}

The extra carly flowering species is the pride of the Southland. It is spreading in growth with arching, slender branches that are perfect $m a s s$ of minute flowers followed with exceptionally delicat a green foliag. For edging purposes it has few equals and we recommend it highly.

Sizes

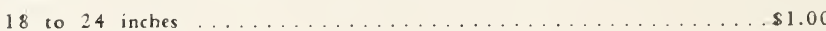

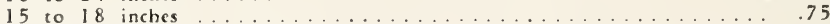

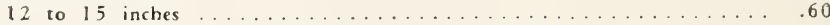

\section{SPIREA VAN HOUTTE (Van Houtte Spirea)}

The well know Bridal Wrrath. Flowers cover enrire plant, making long, gracefui, curving branches of snow-white blooms in early spring, prolonged season. Good among Evergreens for contrast. Fills low places admirably and makes borders of excrllent appearance.

Sizes

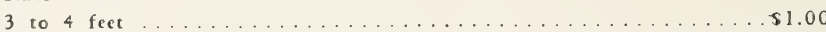

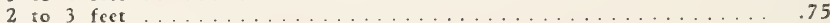

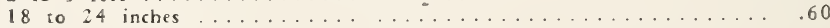

SPIREA ARGUTA (Garland Spirea)

Of seni-dwarft growth, covered with pure white fowers in carly May. Its lace-like foliage causes plants of this variety to be attractive throughout the entira season.

2 to 3 feet ............. 180

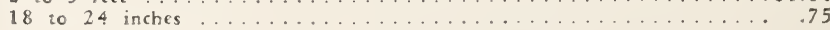


BLUE SPIREA (Caryopteris Incana)

This is one of the rare blue-flowering shrubs. Grouped with white or delicate shades of pink spirea, it makes a colorful mass in early spring and summer.

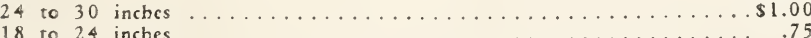

SPIREA ASTILBE (Goatsbeard Spirea)

$A$ beautiful and fascinating shrub. The top dies down during the winter months, while the root remains alive and roady to burst forth in early spring. Flowers are beautiful, being pink, lavender, purple, etc., and their peculiar shape and characteristics give the shrub its common name. "Goatsbeard." We bave some extra nice stock and you will be more than pleased with this shrub.

Sizes

24 to 30 inches Each

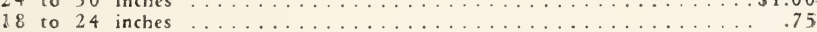

\section{SPIREA BILLARDI ALBA (White Billard Spirea)}

A tall growing variety. Flowers snowy white, produced in long, dense panicles. Commences to bloom in May and lasts throughout the summer.

2 to 3 feet $\$ \ldots .75$

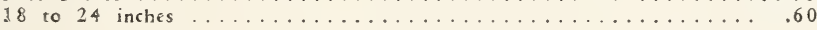

\section{SPIREA BILLARDI ROSEA (Pink Billard Spirea)}

A tall growing variety. Flowers bright pink, produced in long, dense panicles. Commences to bloom in May and lasts throughout the summer. Very showy.

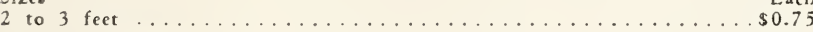

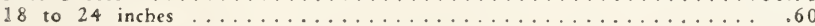

\section{COMMON SNOWBERRY (Symphoricarpos recemosus)}

This shrub has small, pinkish flowers in July, followed by white brries which remain on well into winter. Very attractive, medium-growing shrubs.

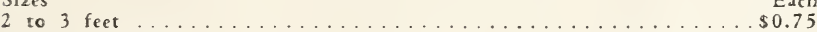

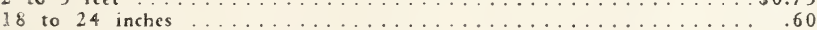

\section{AFRICAN TAMARIX (Tamarix Ãfricana)}

A beautiful shrub with small leaves; similar to the Junip r; flowers are pink, small and delicate, borne on long spikes; bloom in May.

Sizes

3 to 4 feet

2 to 3 feet

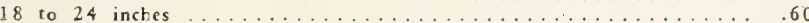

COMMON SNOWBALL (Virburnum Opulus Sterile)

Tho fine, hardy shrub with beautiful large clusters of globular flowers. Bll the flowers are sterile and radiant. An old-fashioned favorite, and one of the finest all-around shrubs.

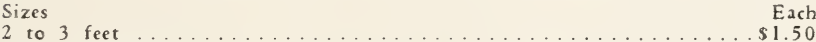

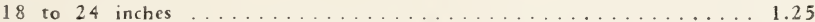

\section{JAPANESE SNOWBALL (Virburnum Plicatum)}

One of the choicrst of the hardy shrubs. Large globular clusters 3 to 4 inches across, of sterile radiant flowers of cleanest white. This is an excellent shrub.

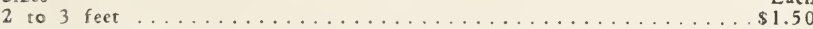

18 to 24 incbes 
WEIGELIA EVA RATHKE (Red Weigelia)

The finest of the cultivated Weigelias. Free blooming. hybrid. with Aowers of a distinctive reddish purple. Unlike other flowering shrubs.

Sizes

Each

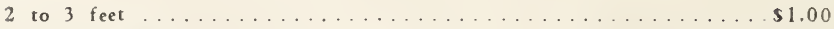

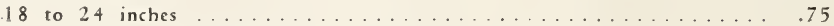

\section{DWAFT VARIEGATED WEIGELIA (Weigelia Nana Variegeta)}

This is perhaps second to no other hard-wood d plant with various colored leaves. It stands the sun well and retains its well marked tints until autumn. The flowers are lighter in color than the Ros-a. but it is equaly as free in bloom.

Sizes

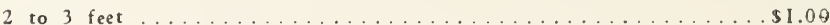

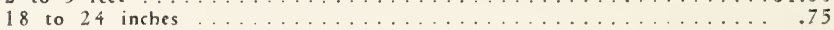

\section{WEIGELIA ROSEA (Pink Weigelia)}

An elegant shrub, with fine, rose-colored flowers: introduced from China by Mr. Fortune and considred one of the finest plants he has discovered. Has numerous spreading branches, leaves dark green, smooth except on the midrib and veins. The flowers are large, showy and produced in griat panicles. Erect, compact growth. Blossoms in June.

Sizes

Each

2 to 3 feet $\$ 1.00$

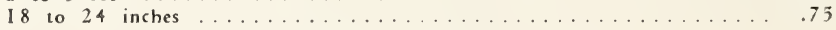

\section{YELLOW TWIGGED DOGWOOD (Cornus Lutea)}

Golden yellow twigs. white blossoms, whit berries. A splendid shrub to place in combination with Coral Dogwood. An unusual lawn decorative sort. Grows 6 to 8 feet high.

Sizes

Each

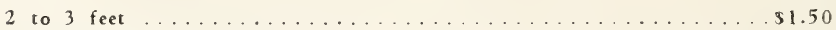

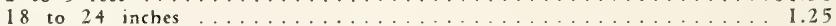

RED TWIGGED DOGWOOD (Cornus Stolonifera)

A spreading shrub with bright, reddish-purple branches, attaining a hinght of 4 to 6 feet. Flowers creamy whit: in dense. fat-topped clusters. Berriez white. Remarkably showy.

Size

Each

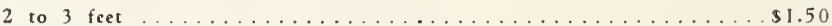

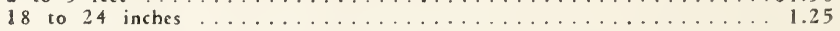

\section{BROAD-LEAVED EVERGREENS}

\section{ABELIA GRANDIFLORA (Glossy Ab lia)}

The most satisfactory addition to the list of hedge plants in years. Can be pruned flat or rounded on top. Planted singly or in groups. will add a rouch of beauty to the lawn all the year round. It is an evergreen shrub with glossy, dark gren foliage. In winter when affected by cold the leaves turn a beautiful shade of bronze and look as though coated with varnish. The flowers are white. funnel shaped, tinted with pink, delicately sweet scented and born: in clusters from May until late in autumn.

Sizes

Each

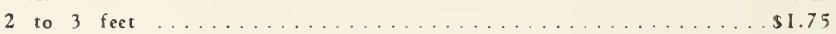

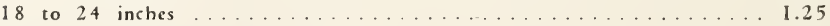

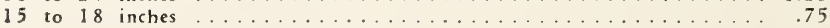

\section{TRUE DWARF BOXWOOD (Buxus Sempervirens Suffuticosa)}

Similar to the tree dwarf. Valuable for low hedges and edging. Sizes

15 to 18 inches

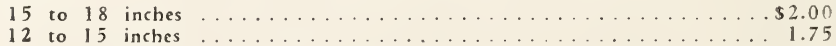

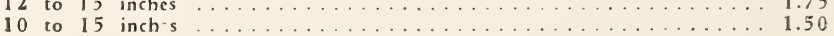

TRUE TREE BOXWOOD (Buxus Sepmervirens Arborescens)

Succeeds most in well drained soils. requiring protection, however, against extremes of both cold and heat. Soms shade is nearly always desirable. 
Leaves small. glossy. bright green, Grows dense, roundish form; valuable for formal planting.

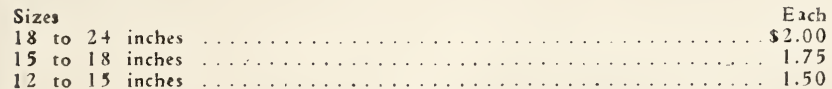

\section{EUONYMUS JAPONICA (Evergreen Euonymus)}

A most popular broad-laved evergreen in this section. Hardy, compact, upright growing, bright, dark green foliage, stands trimming well and shows up beautifully as a specimen plant. Foliage brilliant all winter.

\section{EUONYMUS SEIBOLDI (Patens) (Midwinter Euonymus)}

A very attractive Japanese varicty, with handsome, dark green foliage. Perfectly hardy in any climate. Strong. bushy plants.

Sizes

Each

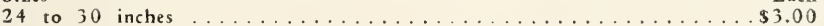

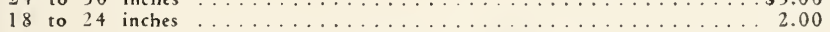

\section{EUONYMUS RADICANS (Winter Creeper)}

An evergrcen climbing vine, or can b. grown as a low srub. Makes a beautifal evergreen covering for a foundation wall. back of a shrubbery planting. Grows in either sun or shade.

Sizes

2 to 18 inches

\section{CAPE JASMINE (Gard nia Florida)}

Very popular evirgreen shrubs with bright, glossy foliage. Hardy as far north as Virginia and Tennessee. They do well in almost any well drained soil. Large, fragrant. white flowers producd from the middle of May until fall.

Sizes

24 to 30 inches Each

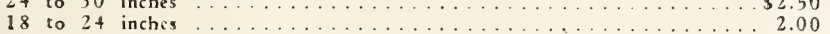

\section{AMERICAN HOLLY (Ilex Opaca)}

Evergreen ornamental tree which produces red berries in the fall. Hardy as far north as cintral Ohio. The kind of holly we get for the Christmas Holidays.

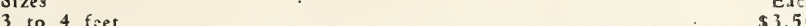

2 to 3 feet

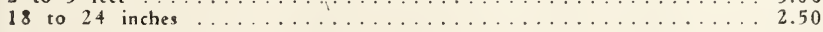

\section{CAROLINA CHERRY LAUREL. (Laurocerasus Caroliniana)}

One of the finest broad-leafed evergreens. Polished medium gren foliage, upright, easily pruned. White, plum-like blossoms in spring. A splendid shrub that cannot be too highly recomm nded. Useful for borders and mixed with shrubs in foundation plantings.

Sizes

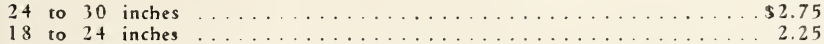

\section{JAPANESE PRIVET (Ligustrum Japonicum)}

Hardy. graceful. one of the finest of all Privets. Spreading and curving branches supporting greyish green foliage. White fragrant flowers produc d in June. followid by black berries. Used in mass planting or hedzes to great advantage.

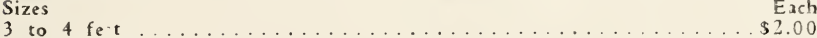

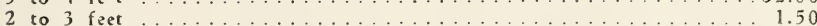

\section{WAX.LEAF PRIVET (Ligustrum Lucidum)}

A lovely form of Japanese Privet. Large, thick leaves. Dark, shining green. White flowers in large heads borne in May, follow-d by black berries which remain throughout the winter. 


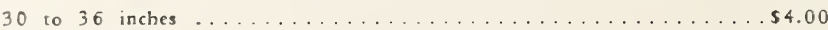

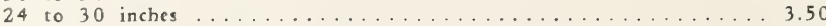

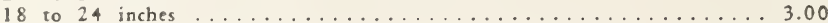

\section{COMPACT NEPAL PRIVET (Ligustrum Nepalense Compacta)}

Medium siz;, dark green, glossy leaves; uniform, compact spreading growth. A very attractive plant, essential to landscape planting in masses, banking or groups. Fills space between tall, rank growing types.

Sizes

Each

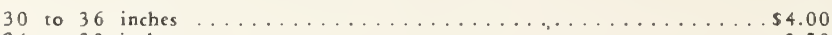

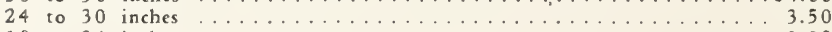

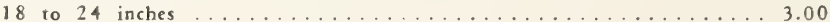

\section{MAGNOLIA GRANDIFLORA (Southern Magnolia)}

A large, handsome tree; foliaget bright glossy green, and large flowers pure white, six to eight inches in diameter. Fine as a specimen, planted in rows and groups.

Sizes

Each

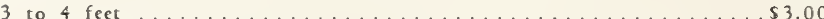

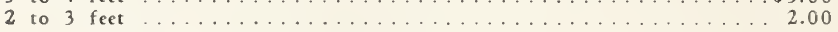

\section{MAHONIA AQUIFOLIA (Origon Hollygrape)}

Dense, low spreading shrub; foliage holly-like, glossy green, changing to purple and bronze; flowers yelow, borne in reacemes. followed by a profusion of blue grapc-like berries.

Sizes

Each

24 to 30 inches $\ldots . . . \ldots$

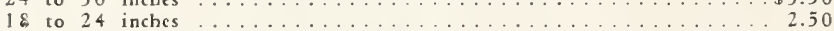

\section{NANDENA DONESTICA (Heavenly Bamboo)}

The delicate foliage of the Nandena is a brilliant dash of georgcous orange red or crimson color in winter. It is densc' and stocky, being one of the dwarfish plants of Japanese gardens. The leaves are rich red when young, dark grcen at maturity, and boldly colored in winter. Nandina thrives wril in any well drained, loamy soil, and is fairly hardy. In autumn it is covered with showy clusters of small red berries. This plant is one of the three plants most us d in better class of landscape work.

Sizes

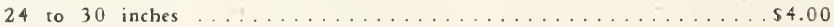

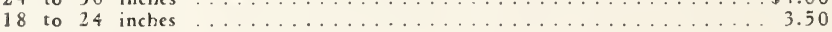

\section{JAPANESE SPURGE (Pachysandra Terminalis)}

This is a new evergreen training plant 6 to 18 inches high and forms broad mats of bright, shiny, green foliage. A good ground cover which will grow in all shady locations, and the only plant that will thrive under pine trecs.

Sizes Each Per Doz.

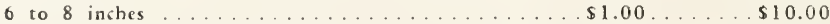

\section{RHODODENDRON (Carolinium) (Carolina Rhododendron)}

A new American species. Clear pink. Absolut ly hardy. This is one of our fincst introductions and fills a long-felt want for a hardy dwarf Rhododendron, with flowers free from any hint of magenta. It was described and named by Alfred Rehd $r$, of the Arnold Arboretum. It is the smallest Alleghanian species, attaining a height of six to eight feet in cultivaiton. The thick-set leaves are dark green, usually blunt and narrow. Much smaller than cither Maximum or Catawbiense. Flower clusters appear in greatest profusion in June, coviring the plant with a rose-colored mantle. Stands exposure unusually well and is invaluable as a single specimen or for massing.

Each

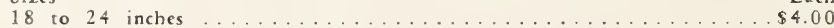

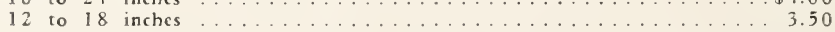

\section{RHODODENDRON (Maximum) (Roscbay Rhododendron)}

Largs, showy green leaves and clusters of pinkish-white flowcrs appearing in late June and early July. More used for mass planting and woodland development than any other specics. 


\section{RHODODENDRON (Catawbiense) (Catawba Rhododendron)}

Vigorous, frec-blooming species with gorgeous display of rosy purple flowers in May. By far the bardiest and most showy of all Rhododendrons.

18 Each

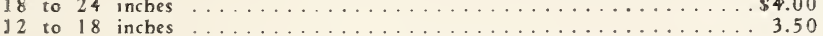

\section{MOUNTAIN LAUREL (Kalmia Latifolia)}

An evergreen shrub covered with rich foliage, glossy green above and yellowish-green on tha under side. Beautiful pink and white flowers borne in profusion the latter part of June. Very hardy, thrives anywhere. A valuable native shrub.

Sizes Each

18 to 24 inches $\ldots \ldots \ldots$

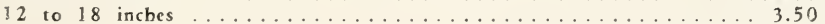

\section{CONIFERS}

\section{CHINESE ARBORVITÃE (Biota Orintalis)}

Pryamidal in form, compact in growth and a bright grecn in color, which it holds well into the winter. Valuable where a tall-growing evergreen is wanted.

Sizes

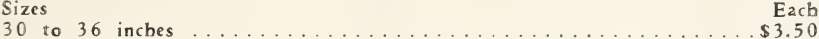

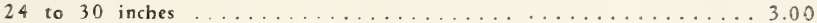

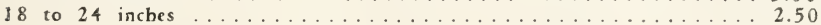

ERECT GOLDEN ARBORVITAE (Biota Aurea Conspicua)

Of pronounced Pvramidal habit of growth; foliage a decp golden yellow. One of the most attractive of the pyramid-growing arborvitaes and very beavtiful. Used in group plantings with the dark foliaged varicties on account of its contrasting foliage.

Sizes

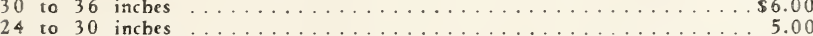

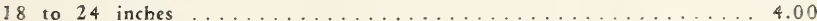

\section{BERCKMÁN GOLDEN ARBORVITAE (Biota Aurca Nana)}

This is, without doubt, the showiest of all the Arborvitae family. The color is an nusually attractive bright gold and is striking in appearance. Does especially well with us and should be in every planting.

Sizes

Each

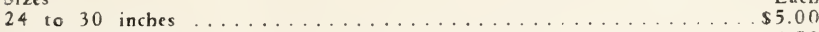

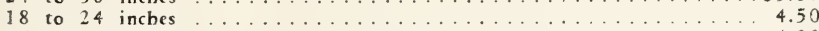

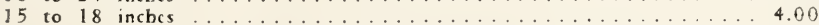

\section{BAKERS HYBRID ARBORVITAE (Bioto Bak ri)}

A fine pyramidal type which is nnexcelled for its tall, columnar growth: foliage soft, light green. The plant, while small, is somewhat irregular in form but when it attains a height of 3 or 4 feet fills out, forming an almost perfict pyramid. This variety is vigorous in growth and its good color makes it distinctive.

Sizes

\section{BONITA ARBORVITAE (Bioto Bonita)}

A beautiful, broad, cone-shaped Arborvitae of unequalled richness in color and perfection of form. The most attractive and useful of all vari tics we grow. Rich green color, half globe shape. Can be planted in most prominent locations as it maks up uniformly. Slow growth makes it desirable in locations where other shrubs would overgrow. Ideal for the finest landscape plantings and most beautiful grounds. No pruning. 


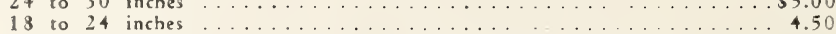

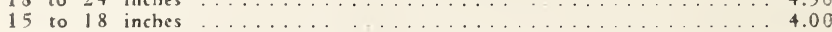

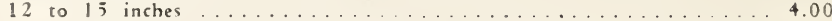

\section{COMPACT CHINESE ARBORVITAE (Biota Orientalis Compacta)}

A fine, dark green varisty of campact. conical growth.

Sizes

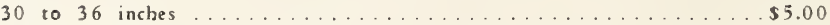

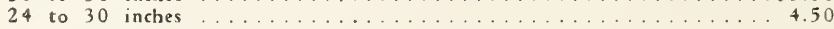

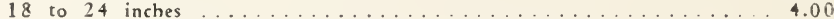

\section{DWVARF COMPACT GREEN ARBORVITAE (Biota Orientalis Daly Nana)}

The best dwarf green form. similar to Aurea Nana in growth, bat with green foliage.

Sizes

Each

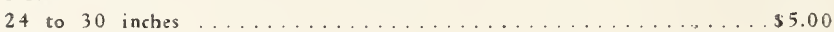

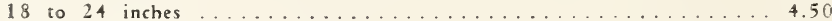

15 to 18 inches ......... 3.50

\section{BLUE-GREEN ARBORVITAE (Biota Hudginsi)}

This is a hadnsome Arborvitate with bluish-green foliage that does not change color in winter. A strong grower and soon makes fine. large. beaurifuil specimens which retain their good apparance. even when old.

\section{Sizes}

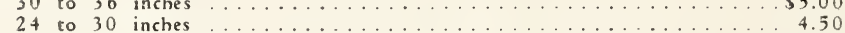

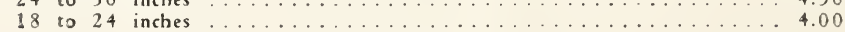

TEXAS BLUE ARBORVITAE (Biota Crientalis Texana Giauca)

Unusually different in its soft blue foliage. A new variety. strong, open growing, pyramidal. upright. Theonly member of the Thuja family with sucb a color. A colorful accent unit.

\section{ROSEDALE ARBORVITAE (Biota Orientalis Rosedale Hybrid)}

Unusual fineness of foliage, feathery, used often in urns due to its perfect 6ymm-tiy, bluish grey foliage tips. dwarf. an arborvitate that always attracts attention.

\section{CEDRUS DEODARA (Deodar Cedar)}

The great cedar of the Himalayan Mountains. A stately tree, attaining beight of 50 to 75 feet, foliage glaucous green; branches feathery and spreading: perfectly adapted to this climate.

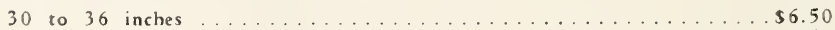

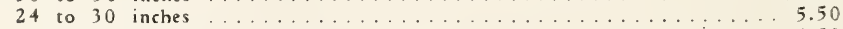

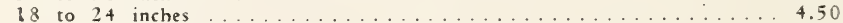

\section{CHINESE JUNIPER (Juniperus Chinensis)}

A conifer that is coming rapidly into favor in this section as it becomes bett-r known. Bright green foliaje, tree shapes up somewhat conelike, but is compact. however. not so dense as to burn out. 
SPINY GREEK JUNIPER (Juniperus Excelsa Stricta)

A very ornamental tree, decidedly conical in form, well branched and $d$ nsely clothed with grayish-green. glaucous foliage. A distinct species of great beauty. Excellent for conifer groups, for specimens or for tubs and urns.

Sizes

E2ch

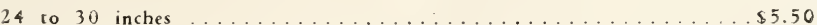

\section{PFITZERIANA SPREADING JUNIPER (Juniperus Pfitzeriana)}

The handsomest of the Chinese Juniper varieties, the Pfitzer is the mose satisfactory of the low-spreading or prostrate type of Juniper that we recommend for the South. Unusually beautiful in its distinctive grayish color and irregular, flat spread growth. For the terrace planting, prominent low groups, about foundations and as specimens it cannot be excelled.

Sizes

Each

24 to 30 inches 18 to $\$ 5.00$

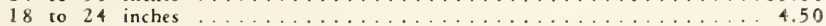

\section{COLUMNAR ENGLISH JUNIPER (Juniper Communis Columnaris)}

This is the English Juniper, of narrow, upright growth and bluish-green foliage. Fine for certain landscape uses where narrow and pointed type is desired.

Sizes

Eacb

30 to 36 inches........ \$4.00

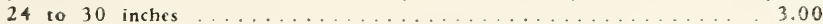

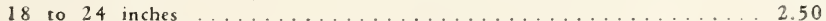

\section{ASHFORD JUNIPER (Juniperus Communis Ashfordi)}

A development from the Ėnglish Juniper, with graceful, oblong branches, of brightest bluish-green color. In contrast to English and Irish Junipers, ashford is loose and wavy.

Sizes

Eacla

30 to 36 inches $\$ 4.00$

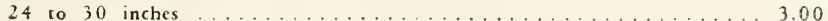

\section{CANADIAN PROSTRATE JUNIPER (Juniperus Communis Canadensis)}

Excessively vigorous, many-stemmed evergrien of rather low-spreading habit. Grows native over a large area of the eastern and northern portions of the continent. Sharp pointed, gríy green leaves that form a luxurous foliage cover.

24 to 30 inches $\begin{aligned} & \text { Each } \\ & \$ 450\end{aligned}$

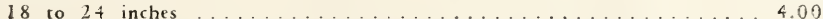

\section{CREEPING JUNIPER (Juniperus Horizontalis)}

Creeping Savin. Dull green leaves. Grows rapidly and makes a very pleasing effect when plant d on terraces.

Sizes

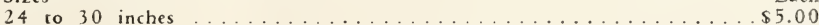

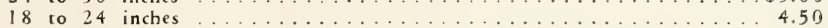

\section{SAVIN JUNIPER (Juniperus Sabina)}

A dwarf, spreading shrub with trailing branches; semi-erect, soft, finc, dark green foliage. A dwarf trailing variety that thrivis in poor soils and is valuable for rockwork and foundation planting.

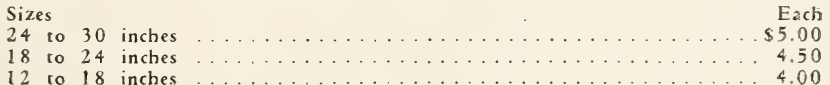

\section{RED-CEDAR COLUMNAR TYPE (Juniperus Virginiana)}

An attractive, well known tree. Pyramidal type. Very hardy. Covered with silvery blue berries in season. Good in background or for shade. Can be kept low by occasional shearing and makes a bcautiful shrub in a folindation or general planting.

3 to 4 feet

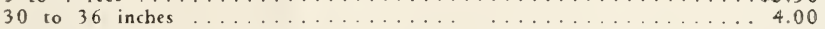

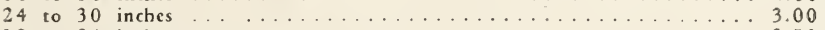

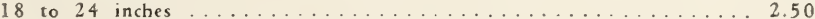




\section{BLUE CEDAR (Virginia) (Juniperus Virginiana Glauca)}

Rich silver-grey foliage all season. A beautiful contrast whin planted among other evergreens. Exceedingly popular everywhere.

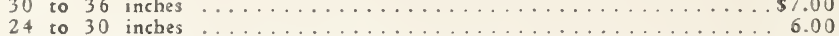

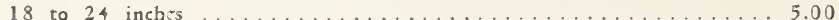

\section{IRISH JUNIPER (Juniperus Communis Hibernica)}

Distinct and beautiful; of a slender, erect, dense columnar growth; foliage very glaucous. Fine for small places as a specimen. also good in masses.

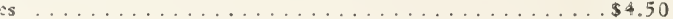

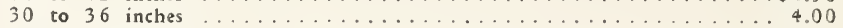

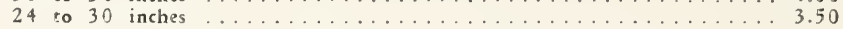

\section{PROSTRATE JUNIPER (Juniperus Prostrata)}

This is a low-spreading plant, very vigorous, many-stemmed and at home on sandy or gravelly hillsides fully exposed to the sun. It grows rapidly but may be kept small by trimming.

Sizes

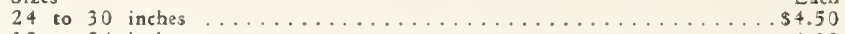

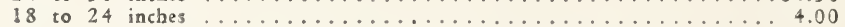

\section{NORWAY SPRUCE (Picea Excelsa)}

Commonest spruce seen; known as the "Christmas Tree." Very hardy and adaprable to hedge or other purposes; leaves dark green; very handsome. Tree of pyramidal, lofty appearance.

Sizes

Eacb

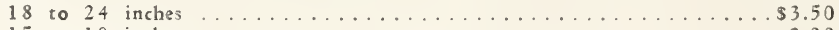

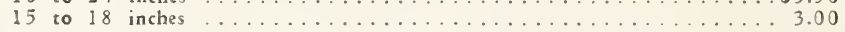

\section{COLORADO BLUE SPRUCE (Picea Pungens Glauca)}

This species has been tested at various points on the prairies of the West and Northwest with perfect success, and during a temperature of 30 degrees below zero. in exposed situations, entircly uninjured. This is the king of spruces.

Sizes

Each

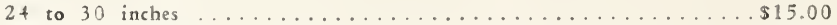

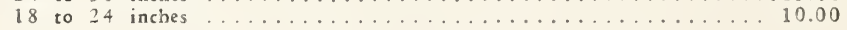

\section{COLORADO GREEN SPRUCE (Picea Pungens)}

Sharp leaves are bluish to dull green and rather thicker than usual. Branchess horizontal, in regular whorls.

Sizes

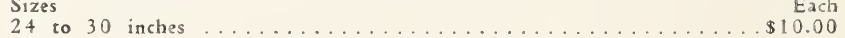

18 to 24 inches ................................... 70

\section{BLACK HILLS SPRUCE (Picea Canadensis Albertiana)}

The Black Hill spruce is hardiestof all spruces-symetrical, compact and bushy in habit of growth: in $\mathrm{fact}$, the very smallest trees soon form round, sturdy, compact bodies.

Sizes

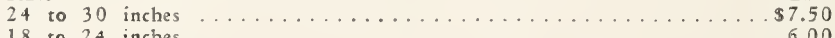

18 to 24 inches .................................... 60

\section{HEMLOCK SPRUCE (Tsuga Canadensis)}

This is considered the best of all evergreens. It is adapted for specimen planting if allowed to grow naturally; if sheared, desirable for foundation planting. Foliage deep green with branches sweeping and graceful. If you are in doubt as to what evergreen to plant we highly recommend this.

24 Each

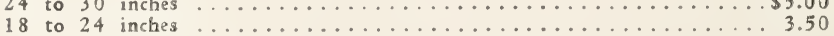

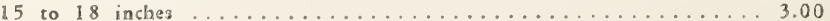




\section{RETINOSPORA PLUMOSA (Plume Cypress)}

Main stems are erect, but side shoots assume a plume-like arrangement, with the leaf-points prominent. The branches are slender and pliable, im. parting a feathery appearance. A good bedge plant. Of graceful habit, with delicate, glaucous foliage.

Sizes

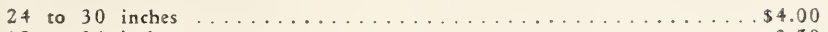

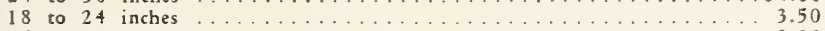

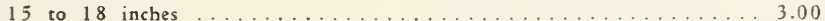

\section{RETINISPORA FILIFERA AUREA (Goldsn Thread Branched Cypress)}

Very bright, conspicuous, golden-yellow. Grows more slowly than preceeding.

Sizes

Each

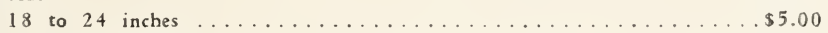

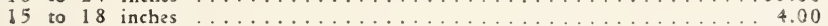

\section{AMERICAN ARBORVITAE (Thuja Occidentalis)}

One of the most popular evergreen becauscof its easiness to transplant, growing kindly under adverse conditions, and as a specimen or hedge plant if is very attractive. It is inclined to be conical in habit of growth and while it is not as green in color as other varieties during the winter, it is one of the most popular varieties because of its many good qualities.

Sizes

Each

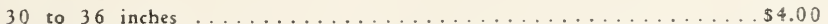

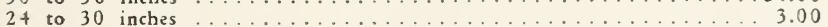

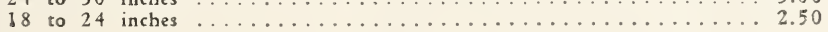

\section{DOÚGLAS GOLDEN ARBORVITAE (Thuja Occidentalis Douglasi)}

Among the golden forms, the Douglas Golden Arborvitae is well known and widely used. It is a form originatcd by Robert Douglas, of the old Douglas Nurseries at Waukegan, Illinois. It forms a broad, bushy, pyramid, very similar in outline to a good type of the regular American Arborvitae. The foliage is decidedly golden, not so bright as Peabody's but usually a better appearing tree than the latter.

Sizes

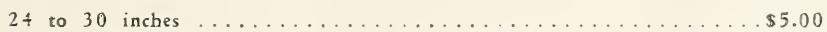

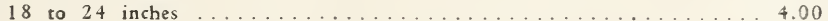

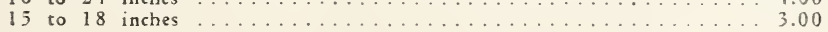

\section{TOM THUMB ARBORVITAE (Thuja Occidentalis Elwangeriana)}

This has very fine-cut foliage and doss not exactly resemble the "pressed" leaves that characterize the other varietis. This is vry compact growing and has a very soft, feathery appearance not found in other evergreens.

Sizes

Each

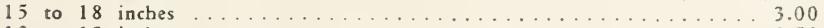

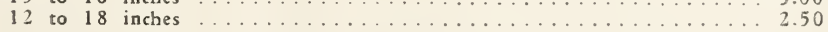

\section{GLOBE ARBORVITAE (Thuja Occidentalis Globosa)}

A dwarf, round, dense head of handsome American arborvitae foliage. Does not require shearing. Foliage deep, dark green, its little branches bcing of unusual delicacy.

Sizes

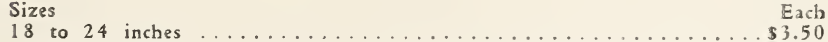

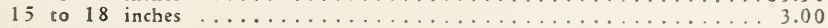

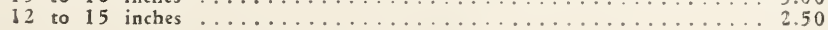

HOVEY'S GOLDEN ARBORVITAE (Thuja Occidentalis Horeyi)

Egg-shap:d form with brigbt green foliage.

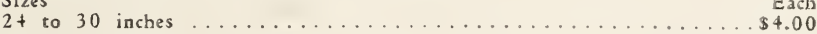

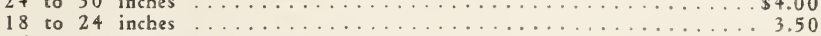

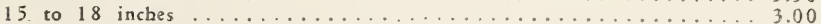




\section{AMERICAN PYRAMID ARBORVITAE (Thuja Occidentalis Pyramidalis)}

This is strikingly attractive, being perfectly pyramidal in shape, spreading very little at its base and retaining the shape without shearng. The color is deep rich green and like all Arborvitaes is easy to transplant. For corners, in front of pillars, center or back ground of group plantings there is hardly an evergreen of the dwarf varicty that is quite so popular.

Sizes

Each

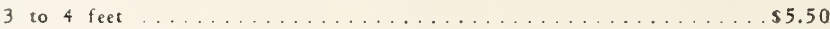

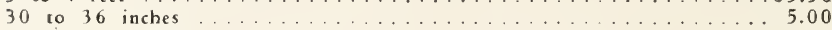

24 to 30 inches ..................... 4.50

\section{GEORGE PEABODY ARBORVITAE (Thuja Occidentalis Lutea)}

This variety is similar to the American Arborvitae, ixcept that the foliage is golden when exposed to the direct rays of the sun. It is by far the best of the American Golden types.

Sizes

Each

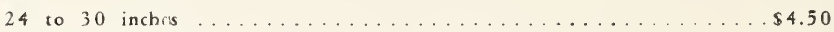

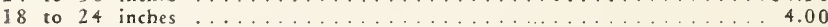

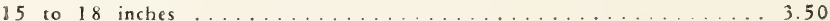

\section{WARE ARBORVITAE (Thuja Occidentalis Wareana)}

This is a small globe variety and its unusually dark green color makes it very useful. It is the darkest gteen of all the American Arborvitais. It can be sheared to a perfect globe though if left to develop naturally it is oblong.

Sizes

Each

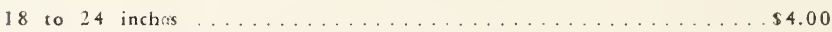

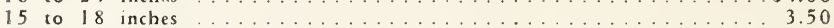

\section{AUSTRIAN PINE (Pinus Nigra)}

The narive forest tree of Europe. Attains 50 feet height at maturity, btoad crown of dark green goliage, needles 4 inches long and born in pairs. A rapid grower, retains its lowest branches. fine for specimen or screening purposes

Sizes

Each

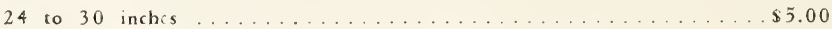

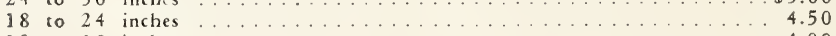

12 to 18 inches $\ldots \ldots \ldots \ldots \ldots \ldots$

\section{HILLS MUGHO PINE (Pinus Mughos)}

Hills Mugho Pine is a tree which is fairly tolerant of shade and it will grow on the north side or the shady side of a building quite successfully. It is without question the outstanding dwarf evergreen tree for all-round uses.

Sizes

12 to 15 inches

Each

10 to 12 inches

$\$ 5.00$ 4.00

\section{BALSAM FIR (Abies Balsamea)}

Regular and symmetrical in growth, hardy. native, thriving in moist soils and cool climates. One of the most beautiful evergr ens grown. and attractive the year through.

Sizes

Each

24 to 30 inches

$\$ 5.00$

24
18 to
8

4.00

12 to 18 inches

3.50

\section{CONCOLAR FIR (Abies Concolar)}

One of the hardiest and most beautiful cvergreens. Tree of gtaceful habit; grows rapidly. Pretcy cones of purple or yellow. Large, broad. silvery-green foliage. A rare and exceedingly choice variety that is indispensable in lawn planting. 


\section{VINES AND CREEPERS}

\section{CLEMATIS}

Our supply of these deservedly popular climbers is now better than ever before. But the demand is great - we suggest prompt orders.

Varicties:

Henryi-Large, ivory-white blooms, freely produced nearly all summer.

Jackmanni-Large, rich, velvety violet-plum flowers. Sizes

2 year No.

\section{VIRGINIA CREEPER (Ampelopsis Quinquefolia)}

This well known native climber is one of the best and quickest growing varieties for covering trees. trellises and arbors. Its large, deep green foliage assumes brillant shades of crimson and scarlet in tha fall.

Sizes

Each

l year transplanted

$\$ 1.00$

HALLS JAPAN HONEYSUCKLE (Lonicera)

A rampant evergreen climber. Native of Japan. Leaves dark green, dens ly covering the vines and branches. White flowers changing to yllow: dlight, fully fragrant; borne in abundance throughout the summer.

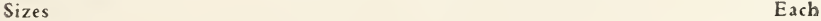

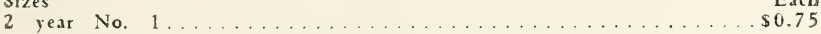

\section{ENGLISH IVY (Dedera Helix)}

Shiny evergreen leaves. Extensively used for covering trunks of palms, trees, walls or pergolas. Hardy endures shade where grass fails. Used to. gether with Boston Ivy to give evergreen coverings throughout the season.

bizes

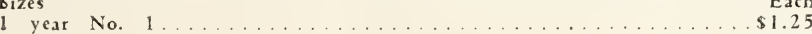

\section{WHITE CHINESE WISTERIA (Sininsis Alba)}

Magnificent, strong-growing. woody vines, hardy throughout the country. Leaves decidious: the flowers are borne in larg? pointed clusters, with or before the leaves in spring. Wisterias make handsome specimens when stakcd and grown as trees. A very fine variety, with large clusters of dolicately scented white flowers.

Sizes

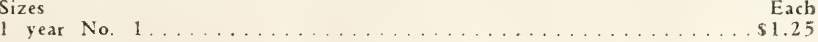

PURPLE CHINESE WISTERIA (Sinensis purpurea)

A very strong-growing sort, producing large panicles of purplé flowers.

Sizes Each

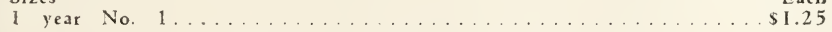

DUTCHMAN'S PIPE (Aristolochia Sipho)

A vigorous and rapid-flowering climber, bearing striking brownish colored flowers, resembling a pipe in shape; very large, round liaves, giving a tropical cffect.

Sizes

Each

2 year No. I ...........................\$1.00

\section{CHINESE MATRIMONY VINE (Lycium Chinense)}

Dul whitisb, purplish; fruit scarlet red. Sizes

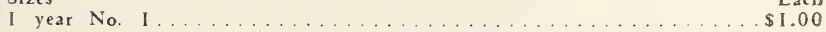

\section{ARMOUR RIVER SOUTH PRIVET (Hedge)}

Ligustrum Amruense (Sinense) Southern Evergreen Hedge.

Most popular and best grade of hedge in the South. Very beautiful evergrcen, dense in growth, dark green. very compact, and establishes a very good hedge in one year. Very hardy and well adapted to general planting. Exceedingly beautiful and permits shearing to any height or shape.

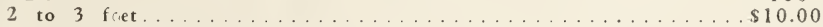

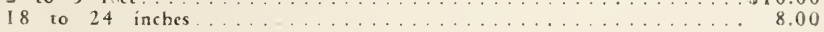




\section{CALIFORNIA PRIVET (Hedge)}

Ligustrum Ovalifolium.

A semi-evergreen hedge with thick, shining leathery leaves, that grows very rapidly, can be pruned into any formal cffect and planted by every one needing a quick hedge without much expense and trouble. It blooms in spring, the fragrant white flowers being noticeable for some distance. In planting it is a good idea to cut away practically all the tops of the smaller piants in order to get a bushy hedge. We have quantities of this desirable variety. Sizes 100

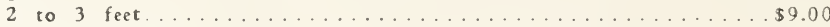

18 to 24 inches ................. 8.00

\section{SHADES}

AMERICAN ELM (Ulmus Americanz)

A trec of unusual vigor. a native ton well known to describe. It is rapid of growth, with its long. spreading and pendant branches forming giant arches over roads and streets or as a lawn tree is quick to make a marked growth. The wood is tough, the leaves are modiate in size and makes a permanenc trce for shade. The bettle that defoliates the European. Elms usually avoids these.

Sizes Each

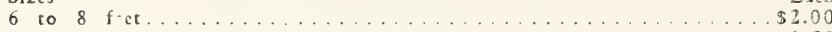

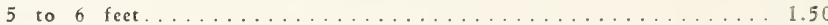

\section{AMERICAN SYCAMORE (Platanus occidentalis)}

Omong deciduous trees the Sycamore is one of the most rapid-growing. It is easily transplanted, even in large sizes. The white trunk, wide-spreading branches, and large leaves mark it as an unusua! and attractive long-lived tree. Sizes Each

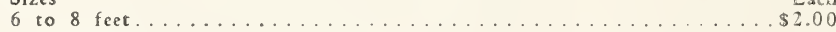

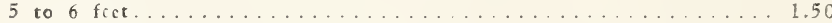

\section{NORWAY MAPLE (Acer Platanoides)}

The Norway has always been a popular tree in this districe, and still remains the most popular shade tree. Large, handsome, spreading, rounded form, broad, decp green foliage. Hardy. Scarce in the pasz few years, but fortunately we have a good stock now ready for market.

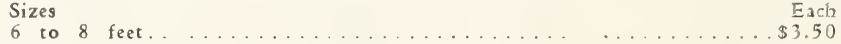

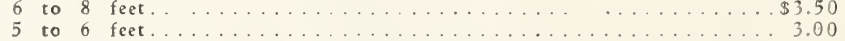

\section{SILVER LEAF MAPLE (Acer Dasycarpum)}

Because of its quick growth, good foliage and easy to transplant, this tree is in grcat demand. The tree blooms very early in the spring. leaves appear. promptly, being light green in color but silvery beneath, and these ramain until late fall.

Sizes Each

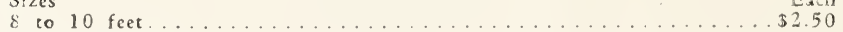

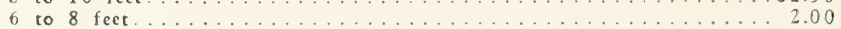

\section{CATALPA BUNGII (Manchurian Catalpa)}

This tree has become popular because of its straight stems and symmetrical roundish heads which resemble an umbrella. The rop are dwarf and while they do not grow very rapidly their wide leaves give them the appearance of much larger trees. The foliage is very pleasing and the effect obtained whon planted in pairs along walks, drives or entrances is greatly admired.

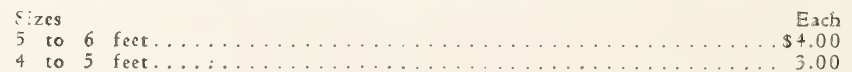

\section{LOMBARY POPLAR (Nigra Italica)}

A tall, slender tree reaching great heights, very easy to transplant and of most rapid growth. For screening unsightly views, fire protection from close buildings or wind breaks, also for quick effect along driveways, natrow avenues, congested lawns, etc. 


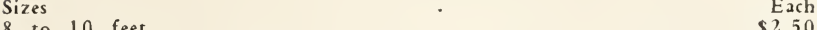

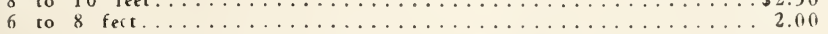

\section{WEEPING WHITE BIRCH (Betula Alba Pendula)}

A beautiful tree with white bark and with spreading and pendulous btanches when mature. Native of Europe. Leaves deip green in sunmer with tones of yellow in autumn. This graceful tree is a handsome lawn tree. The birches always form inter:sting contrasts to other trees and to evergreens.

Sizes

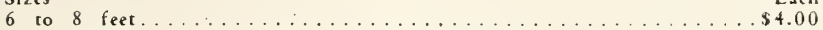

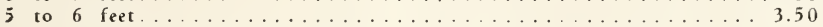

\section{RED BUD-JUDAS TREE (Cercis canadensis)}

A native of our woods, literally covered with its ted or pink blossoms early in the spring before it opens its Icaves. It is an early harbinger of spring, blooming in April. It is a sinall shapely tree. wood very tough, and the leaves large and very green in color. It may be us $d$ in heavy mass planting of shrubs with White Flowering Dogwood or against evergreens or White Birch, making a pleasant contrast.

Sizes

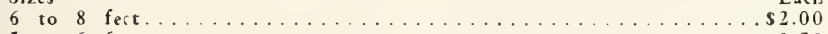

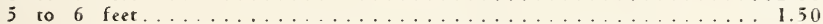

\section{AMERICAN LINDEN (Tilia Americana)}

This native tree is rery atractive and will grow rapidly when planted in low ground. The leaves are distinctly larger than other variaties, branches pendulous in habit of growth and makes an excellent shade tree under favorable conditions.

Sizes

$\$ 3.50$

\section{TEAS WEEPING MULBERRY (Morus Alba Pendula)}

A very odd tree, immediately attractive with its long sweeping branches that touch the ground. It is grafted on its parent stock Russian Mulberry, and is entirely free from all diseases. Bears some fruit.

2 year heads $\$+.50$

TULIP POPLAR (Liriodendron Tulipifera)

A large and stately rapid growing tree with a narrow pyramidal crown. Fowers are cup-shaped, tesembling a tulip, greenish yellow blotched with orange.. A handsome trie and one that is deserving of the highest esteem by planters. Much in demand for planting in parks and estates.

6 to 8 feet

5 to 6 feet 2.00

\section{ROSES}

Sizes

H. T.-Hybrid Tea; H. P.-Hybrid Perperual; M-Moss Rose.

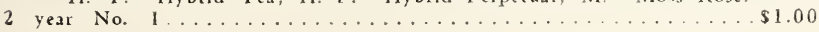

Vatieties-Climbing:

\section{CRIMSON RAMBLER}

The best-known and most popular of all the climbing roses. A rapid grower. making sometimes 10 to 15 fect in a season: flowers are borne in clusters of 15 to 25 perfectly shaped blossoms of a rich glowing crinason: when in full bloom the vine appears to be a perfect $m a t$ of rich red flowers; perfectly hardy cverywhere.

\section{DOROTHY PERKINS}

A hardy, vigorous spring blooming climber which is always dipendable for porches, pergolas or for training banks. Great cluster of small, very double, shell-pink flowers. 


\section{PAUL'S SCARLET CLIMBER}

No other rose in any class can compare with it for brilliancy of color. which is a vivid scarlet. This color is maintained without burning or blaching until the petals fall. It makes a brilliant display during long season. Blooms are of medium size. semi-double, very freely produced in clusters of threc to six flowers each. Plants are laterally covered with flowrs from top to bottom. It is of strong growing habit and perfectly hardy.

\section{CLIMBING AMERICAN BEAUTY}

Rich red, fragrant. Very vigorous in growth and a prolific bloomer. having hundreds of perfect flowers open at one time'.

\section{TAUSENDASHON (Thousand Beauties)}

A rapid growing, almost thornless climber showing the blood of the Rambler, Polyantha and Tea parentage. Its innumerable clusters make a pretty show in June and July; at first, the soft pink of Clotilde Soupert, and later deepening to a bright red carmine rose.

\section{AMERIRCAN PILLAR}

A profusion of rich, rosy blooms almost covering the foliagr. Large single flowers, rigorous. A valuable climber.

Varieties-Bush:

\section{LOS ANGELES (H. T.)}

Produces a continuous succession of long-stemmed flowers of a luminous flame pink, toned with coral and shaded with translucent gold at the base of petals; in richness of fragrance it equals in intensity the fincst Marechal Ncil. The buds are long and pointed.

\section{KILLARNEY, WHITE (H.T.)}

$\Lambda$ pure white sport of the famous and popular pink Killarney, producing the same beautiful flowers in great profusion. The flowers are long and shapely. This is one of the very best hybrid teas.

\section{J. L. MOCK (H, T.)}

The color is carmine on the outsid, and imperial pink on the inside of the fower. The blooms are very large, perfectly formed, and highly perfumed. Plant an entire rose bed of this one kind. Very satisfactory for bedding.

\section{FRAU KARL DRUSCHKI (H. P.)}

The only absolutely pure white rose, with immense long buds and rery double flowers, wax-like in texture. Hardy cherywhere, with foliage of its class. Blooms continuously,

\section{COTUMBIA (H. T.)}

Strong stiff petals of bright pink, sweetly fragrant, healthy foliage. Irs only fault lies in producing malformed blooms when weather conditions are not at their best, but this may be forgiven for in the Fall it blooms Iuxuriantly.

\section{GRUSS AN TEPLITZ (H. T.)}

Dark rich crimson, passing to velvety fiery red. An exceptionall free bloomer and one of the brightest colored red roses grown. The can's are strong and vigorous. producing blooms constantly from June till frost. An almost continuous bloomer.

\section{SOUVENIR DE CLAUDIUS PERNET (H. T.)}

Constance $X$ unnamed seedling. Awarded the Bagatelle prizs. Its color is a definite and lovely sunflower yellow. deepening in the ccnter. and it retains this color indoors and outdoors. in bud and open bloom. The buds. are produced on long, stiff stems.

\section{ETOILE DE FRANCE (H. T.)}

Rich velvety crimson, ccnter ruby red; large and double. Likes hot weather.

$$
\text { RED RADIANCE (H. T.) }
$$

The wonderful, globular, heavy-stemmed "Radiance" duplicated in all respects except color; this sport form being a brilliant crimson. 


\section{SUNBURST (H. T.)}

Color a rich cadmium-ycllow, with orange-y llow center. A magnificent freeblooming varicty, especially handsome in bud form. A vigorous grower with flowers of elongated cup shape. The planr is rather spreading in habit of growth and has few thorns. One of the mosr r liable ycllows for cutting.

\section{MADAME BUTTERFLY (H. T.)}

Strong, light pink buds tinted with gold at the base, heavily perfumed. exquisite form. Although the buds may be slightly marred with heat early in the scason, they quickly assume their perfect form.

\section{AMERICAN BEAUTY (H. P.)}

Very large blooms of rosy-carmine veined wirh crimson. Does particularly well in the Imperial Valley and Arizona, but of no value on the coast.

\section{PAUL NEYRON (H. P.)}

$\Lambda$ rich, ruddy pink, "color spot" of the fall.

\section{LUXEMBURG (M.)}

$\Lambda$ distinctive decp y llow. A beautiful rose.

\section{PERENNIALS}

\section{HOLLYHOCK (Althea Rosea)}

The hollybock is an old garden favorite, full of sentiment and association with a distant past. They require a deep, rich soil and a sunny corner, but will repay by th ir gorgcous and lavish bloom all the attention bestowed upon them. Hollyhocks planted in the fall will bloom the next summer.

Price, each

Price, per

\section{CHRYSANTHEMUMS.}

These are hardy and most attractive in September and October. In planting these try to group them as, some seasons it may be necessary to save from early frost by covering. The flowers are very attractive borne in large quantities. Colors: White, Red, Pink, Yellow.

Price, each

Price, per ten

\section{LARKSPUR (Dclphinium)}

English Delphiniums are the most beautiful hardy plants in cultivation, for they have such an immense varicty of bcauty and increase in size, in beauty, and often in quantity, year after year.

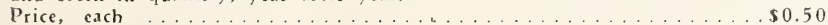

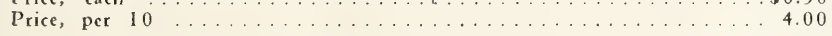

OLD-FASHIONED SWEET WILLIAM (Dianthus barbatus)

Old favorites, bearing their sweet, clove-scented flowers in the gratest profusion during May and June. They are indispensable for the cdg of the hardy border and for cutting.

Price, each $\$ \mathbf{\$ 0 . 5 0}$

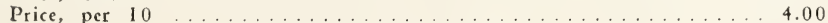

\section{FOXGLOVE (Digitalis)}

For statcly and picturesque beauty it is not to be surpassed. and, plapted in masses and in the gard $n$ among shrubs or naturalized on the edge of woods, in the orchards or along brooks, it is extremely effective and satisfactory. It is a biennial, but as it rencws itself from self-sown seed, it may be trated as a perennial.

Price, each $\$ 0.50$

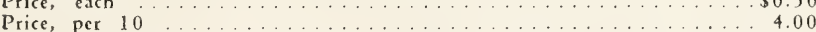

\section{IRIS (Germanica)}

Commonly known as flag iris. Easily grown, long-lived plants that thrive on practically any soil and are perfectly at home in damp soil. Blooms in early spring: flowers large and showy, produced in many colors and shades.

Price, each .......................... $\$ \ldots 0.50$ Price, per $10 \ldots \ldots . \ldots \ldots$

Varicties: Pumila White, Pumila Purple.

\section{IRIS (Japan)}

This is the latest blooming of the Iris. Anyone not familiar with these has missed one of the glories of the gard $n$. They bloom in June, being the largest, showiest and contain varieties that for variance of color and beauty are unsurpassed by any perennial. Prefers moist soil, but blooms exceedingly well on any type. 
Varieties: Eumee, blue: Koko-No-Iro, royal purple petals, yellow centcr; Mahogany, dark red: Patrocle, Signel, superb dark reddish violet: Purple and Gold. double flow: rs. early and free blooming. color rich violet-purple with white petaloids, tipped violet, conspicuous golden throat extending outward in bulish white rays.

\section{IRIS (Siberian)}

Vigorous. frec-flowering varieties of the Iris for the flow $r$ border, for naturalizing planting.

Varicties:

Orientalis white. Similar to the Sibrica varieties but not so tall.

Perry's Blue. Very larg. clear blue flowers on stout. stiff stems, a vigorous frec grower and very free-flowering, one of the best for cutting.

Snow Queen. An exquisite $n$ w hardy Iris; the flowers are of a snowy whiteness, large and well formed, produced in great abundance; foliage light and graceful. A gein for flower border or wat rside.

Price, each ............................... $\$ 0.50$

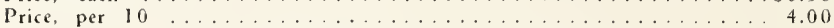

\section{GOLD BANDED LILY (Lilium auratum)}

Undoubtedly one of the fincst. Its large, graceful, fragrant flowers are composed of six petals of a delicate ivory-white color, thickly studd d with chocolate-crimson sport and stripe through the center a golden yellow.

\section{LILY OF THE VALLEY (Convallaria)}

This is often starvid and neglected and $r$ legated to some poor corner, but this popular and fragrant subject, like most other plants, repays for being well treated, and if tle bed is given a liberal top dr ssing of well decayed manure in fall or early spring it will show the effect by increased size. number and vigor of flowers. Pips, white, May.

Price, each

Price, per 10

\section{HARDY PHLOX (Phlox Decussata)}

Th se beautiful hardy border plants are among the most effcctive in the garden during the late summer and fall months. The varieties have been much improvad during the past few years, both as to color and size of bloom. Colors: pink, purple, red, whit:?

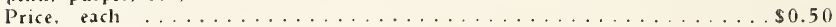

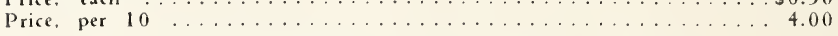

CHINESE LANTERN PLANT (Physalis Francheti)

An ornamental variety of the Winter Cherry forming dense bunches about two feet high, producing freely its bright orange-scarlct, lant rn-like fruits, which when cut, will last all winter.

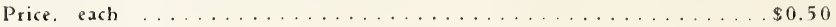

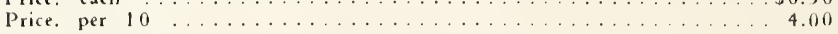

\section{HARDY PANSIES (Viola Cornuta)}

This is the best edging plant for the hardy border or garden: when properly cared for. th se plants remain in full bloom from May until October. The great secret of the continuous bloom; though, is the fact that they must be sheared several times during the year. so that the flow.rs do not yo to sied.

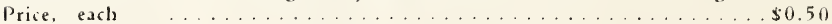

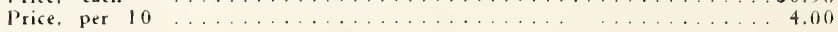

\section{PEONIES}

The Peony does best in a location sheltered from the long. hot. aftarnoon sun and an castern exposture is preferable. The soil should be thoroughly pr:pared and enriched before planting. We recommend planting in Octobir and November for best results. although satisfactory results have been obtained from plantings made as late as February or March.

Named varieties, red, white, and pink, price, each.

\section{CANNAS}

Cannas are easily grown and will thrive in almost any soil but where a choice soil is available we recommend it, with pl nty of sunshinc. Cannas are best when planted in the spring.

Varieties:

King Humbert. Truly the king of Cannas. Its foliage which is of large size and dup bronze is striking: llowers are borne in great profusion and are $a$ rich coppery scarlet. We know of no better general purpose Canna.

Florence Hall. Salmon pink.

Yellow King Humbert. A sport of King Humbert but with green foliage and gold $n$ ydlow flowers dotted with marking of red. Beins a sport of Kiug Humbert a certain percentage of these plants will go back to the parent and occasionally there will be plants with bronze foliage and scarlet flowers.

Mrs. Alfrad F. Conard. B autiful salmon-pink flowers, green foliage. Fine for cutring and beautiful when used in mass planting or for closely sec beds.

The President. An exquisite red-crimson blooming canna, buge, vigorous 
and universally proclaimed the fincst of red varieties, growing upon set beds.

Statue of Liberty. Brilliant red, colored with dull orange.

Price, each

$\$ 0.35$

Price, per 10

3.00

\section{DAHLIAS}

Dahlias are easy of culture and fascination to grow. Sometimes they are called "Man's Flower," because so many men bave taken up dablia growing habit. Our dablia contains the best of the commonest sorts which are the most reasonable and the choicest new varieties which we can recommend to most reasonable and the choicest new varieties
those who are sieking the aristocrats of Dahlias.

Price, each

Price, per 10

\section{GLADIOLUS}

Brighten your garden and your living room with delightful spikes of gladious. There is no cut flower more truly decorative or popular. Beantiful colors in svery shade imaginable. The bulbs may be taken up in the fall and stored for bloom year after year.

Price, per 100

$\$ 15.00$

\section{TUBEROSES}

This charming variety begins to flower in July and continues throughous the season, each bulb throwing from 2 to 5 flower spikes in succession. The buds never blast, but all open up of the purest white, and are delightfully fragrant.

Price, each

Price, per 10

$\$ 0.25$

rice, per 100

\section{TULIPS}

In no other flower has Dame Nature bestowed more brillancy or varicty of coloring than the tulip: and coming into bloom almost with the first blush of spring, when there is little else to gladden the eye, makes it the more refresh ing and desireable. Not only is the tulip gorgeous in coloring: but its beau tiful cup-like form is most exquisite and borne well above the bright green. spear-like leaves. Nothing will afford more satisfaction or attract more atten tion than a well arranged bed o tulips.

Price, per ten.

$\$ 1.50$

Price, per $100 \ldots 12.00$

\section{CROCUS}

These gay little plants are among the first to open their baatiful faces in responce to the first warm spells of early spring sunshine. Planted as an edging in lines of one or more colors the effect is striking and beautiful as nn spring display surpasses that of the Crocus, with their bright colors, and there is nothing to detract from them as they come forth when all else is still shrouded in the sombre shades of winter and often when banks of snow still still to be seen in the shaded nooks. In lawns and parks, planted in the grass the Crocus is extremely effective. They may be easily planted in the sod after it has been softened by rains late in the fall, with the aid of a dibble. and they are blooming before the lawn requires to be mown in the spring. It is now customary to plant Crocuses, Snowdrops and Daffadils in lawns, along woodland walks and in wild places, with an effect that is delightful and matchless.

Price, per 10

Price, per 100

\section{HYACINTH}

When we consider their matchless beauty, rare fragrance and hardiness and ease of culture, it is not to be wondered that the Hyacinth is the most popular bulb grown. They may be had in both single and double, and a variety of colors, and are equally desirab!e for house or out-cloor culture.

Price, each

Price, per 10 pro. $\$ 0$

Price, per $100 \quad 35.00$

\section{NARCISSUS OR DAFFADILS}

The Narcissus has more points of real merit than most other hardy plants. and the possibilities of the family have only recently developed. They are equally well adapted for the conservatory, window garden. flower garden or border, and its culture is the same of the Hyacinth. Three or four bulbs may be grown in a single pot, and may be planted any time from October to January. For bedding or borders in the open ground they should be planted in October or November, and should be set from four to five inches deep, the larger varieties from five to six inches apart and the small varieties three to four inches. In the garden they may be planted in any ont-of-the-way place, and will coninue to bloom and thrive year after year without care or atention and will be among the first to respond to the blandishments of spring

Price, each.

Price, per 100 


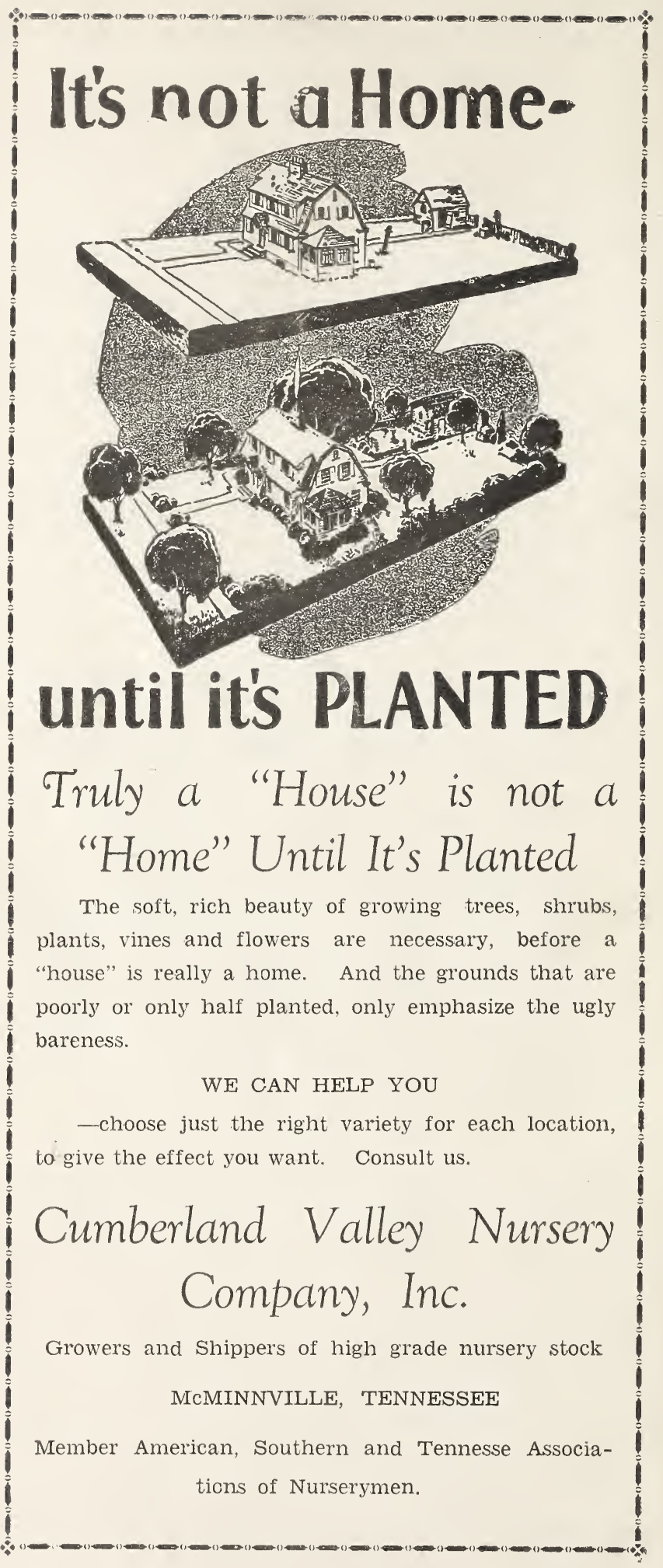

